\title{
NORDIC BIOECONOMY
}
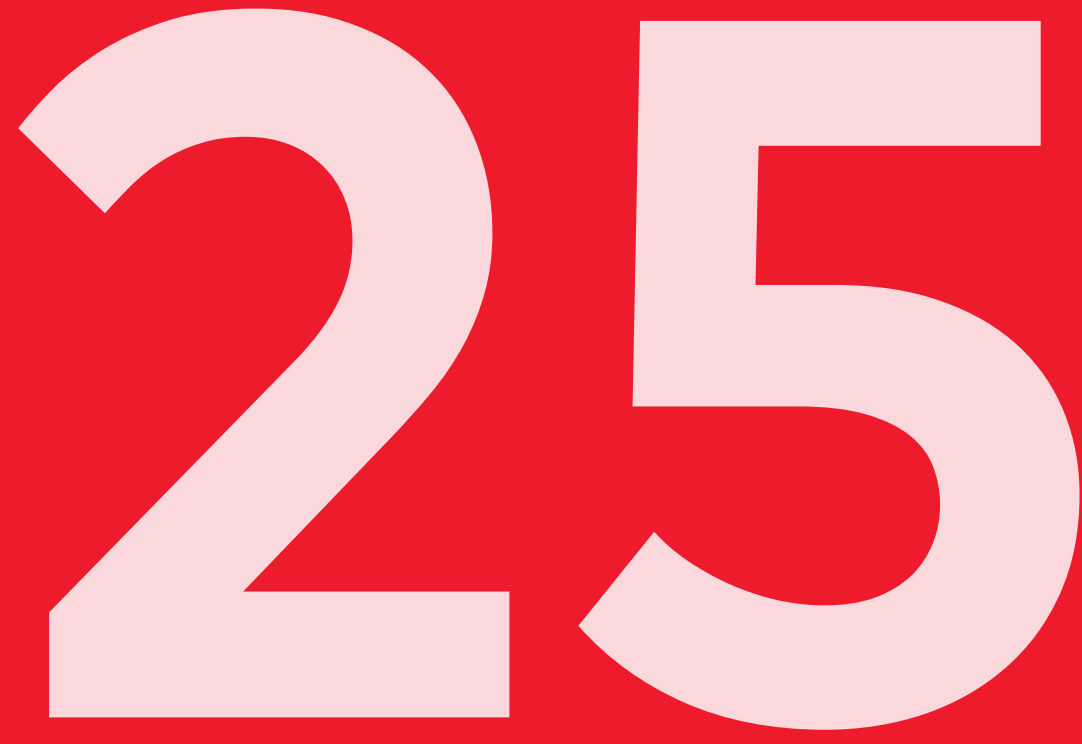

CASES FOR SUSTAINABLE CHANGE

\author{
III) Nordic Council \\ of Ministers
}


Nordic Bioeconomy

25 cases for sustainable change

ISBN 978-92-893-4775-4 (PRINT)

ISBN 978-92-893-4776-1 (PDF)

http://dx.doi.org/10.6027/ANP2016-782

ANP 2016:782

(c) Nordic Council of Ministers 2017

Editor: Liv la Cour Belling

Layout: Jette Koefoed

Print: Rosendahls

Copies: 400

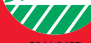

Printed in Denmark

This publication has been published with financial support by the Nordic Council of Ministers. However, the contents of this publication do not necessarily reflect the views, policies or recommendations of the Nordic Council of Ministers.

www.norden.org/nordpub

\section{Nordic co-operation}

Nordic co-operation is one of the world's most extensive forms of regional collaboration, involving Denmark, Finland, Iceland, Norway, Sweden, and the Faroe Islands, Greenland, and Åland.

Nordic co-operation has firm traditions in politics, the economy, and culture. It plays an important role in European and international collaboration, and aims at creating a strong Nordic community in a strong Europe.

Nordic co-operation seeks to safeguard Nordic and regional interests and principles in the global community. Common Nordic values help the region solidify its position as one of the world's most innovative and competitive.

\section{Nordic Council of Ministers}

Ved Stranden 18

DK-1061 Copenhagen $\mathrm{K}$

Phone +4533960200

www.norden.org 


\section{NORDIC BIOECONOMY}

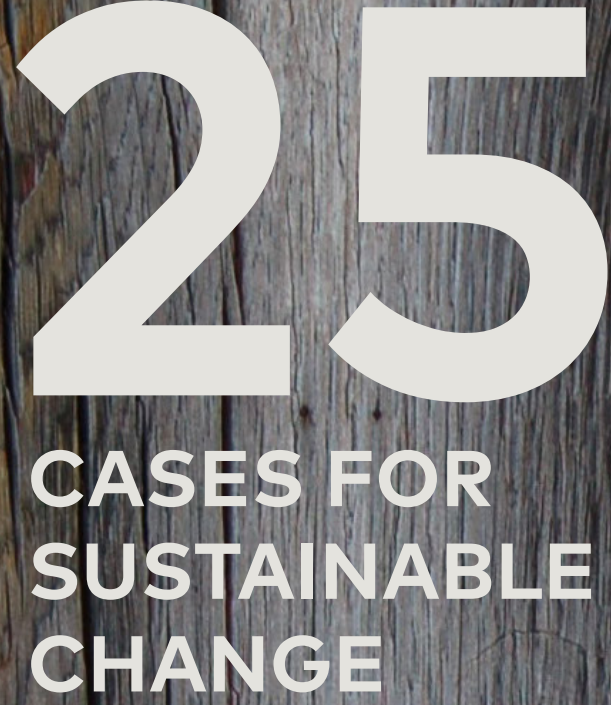




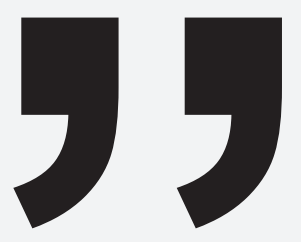

The times

they are

a-changin'

Bob Dylan, 1964 


\section{Preface}

The Nobel Laureate 2016, Bob Dylan, recorded the memorable words "The times they are a-changin'" in 1964. His words have never been truer when it comes to the bioeconomy. The bioeconomy is all-encompassing and comprises those parts of the economy that make responsible use of renewable biological resources from the land and water for the mutual benefit of business, society and nature. It involves tackling major challenges, both now and in the future. These include the sustainable production of sufficient nutritious and safe food for our growing population, developing new and more environmentally friendly sources of energy, and combating global warming, which can have serious consequences both on land and in the oceans. Changes in terms of demographics and digitalisation also call for new solutions.

It is important that the Nordic countries draw up national policies and plans to address those challenges, but it is even more important that we come together to find lasting solutions to advance all areas of the bioeconomy. The Nordic countries are strongly placed to be global leaders in the production and utilisation of bio-resources that will enhance both competitiveness and sustainability. To continuously develop and improve this position we need inspiration and sharing of knowledge and best practices.

To contribute to this development the Icelandic Chairmanship Program for the Nordic Council of Ministers initiated a Nordic Bioeconomy Panel, with the aim to make a proposal for a Nordic bioeconomy strategy. The first step to that strategy is to collect and categorize a catalog of the Nordic bioeconomy.

In this catalogue, we present just a selection of the many excellent cases that deserve attention, but the selected cases seek to illustrate the diverse bioeconomy activities in the Nordic countries. We hope that they will inspire you and enhance your understanding of the bioeconomy, its importance and its potential.

The times are indeed a-changin', and to succeed we need to have the courage to think very differently, find new solutions and come together in collaborations that transcend sectors and involve partners we never imagined working with before.

Hörður G. Kristinsson,

chair of the Nordic Bioeconomy Panel 


\section{COUNTRIES}

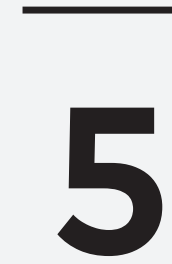

CRITERIA

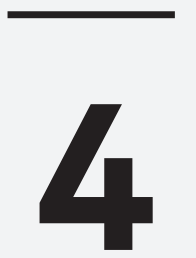

STRONGHOLDS

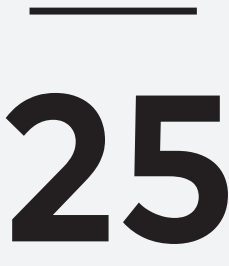

CASES

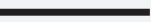

NORDIC BIOECONOMY
SUSTAINABLE CHANGE 


\title{
CONTENTS
}

\section{REPLACE}

\author{
17 Sustainable building solutions \\ 19 From petroleum-based to bio-based additives \\ 20 Wood-based pharmaceuticals \\ 21 Renewable diesel from wood \\ 23 Fish feed from seaweed \\ 25 Fly away on wood pulp
}

\section{UPGRADE}

31 Maximum value from every part of the cod

33 Using the whole fish: From 50 to $90 \%$

34 Turning tonnes of waste into new products

35 New nutrition supplements from slaughterhouse sidestreams

37 From waste shells to flour

39 Upgrading cheese-waste to protein powder

41 Upgrading plant materials to high-value products

43 Self-sufficient and sustainable farming

45 Turning waste into new products

\section{CIRCULATE}

51 Seaweed for food, feed and fuel

53 The Blue Lagoon industrial symbiosis

54 Responsibly produced rainbow trout

55 Regional industrial symbiosis

\section{COLLABORATE}

61 Town transition to a carbon-neutral society

63 From technology park to biorefinery cluster

64 Innovation program for Swedish bioeconomy in 2050

65 A cluster that connects the dots

67 Reinventing the local value chain

69 Local transition to a knowledgebased bioeconomy 


\title{
Introduction
}

\author{
Nordic bioeconomy in a nutshell - solutions for a sustainable future \\ The 17 sustainable development goals towards which nations are obligated \\ to work between now and 2030 are indicative of a global consensus on what \\ constitutes good and fair development - with regard to current civilisations, \\ future generations and the planet as a whole. The global population looks set \\ to reach nine billion people in 2050, which according to the UN will necessitate \\ a $50 \%$ increase in both food and energy production. How can we secure basic \\ needs while limiting negative environmental impacts?
}

The process will involve trade-offs - cultivating the land and harvesting the oceans has an undeniable environmental impact. But changing the way in which we produce and consume natural and cultural resources means that we may not need to increase our usage of them by $50 \%$. We do, however, need to be $50 \%$ smarter and more sustainable.

\section{The bioeconomy}

The bioeconomy consists of the management of renewable biological resources and their conversion into food, livestock feed, bio-based products and bioenergy via innovative and efficient technologies. It means utilising biomass to its maximum sustainable potential in terms of both volume and value - in other words, using every part of the biomass and using it intelligently. The bioeconomy covers all kinds of products: energy, biofuel, heat, construction, bioplastics, smart packaging materials, food, livestock feed, ingredients, textiles, health and pharmaceuticals, just to name few.

As such, the bioeconomy integrates a number of solutions for a future that is more sustainable - environmentally, socially and economically. The bioeconomy makes up more than $10 \%$ of the overall Nordic economy - and in some countries, this figure is steadily moving towards $20 \%$. As most of the production is based in rural and coastal areas, it boosts development in more peripheral areas of the Nordic Region. A holistic approach to the development of a sustainable bioeconomy is imperative, because in a world with limited resources and a changing climate, resource resilience is a cornerstone of community resilience.

\section{How can we secure basic needs while limiting negative environmental impacts?}



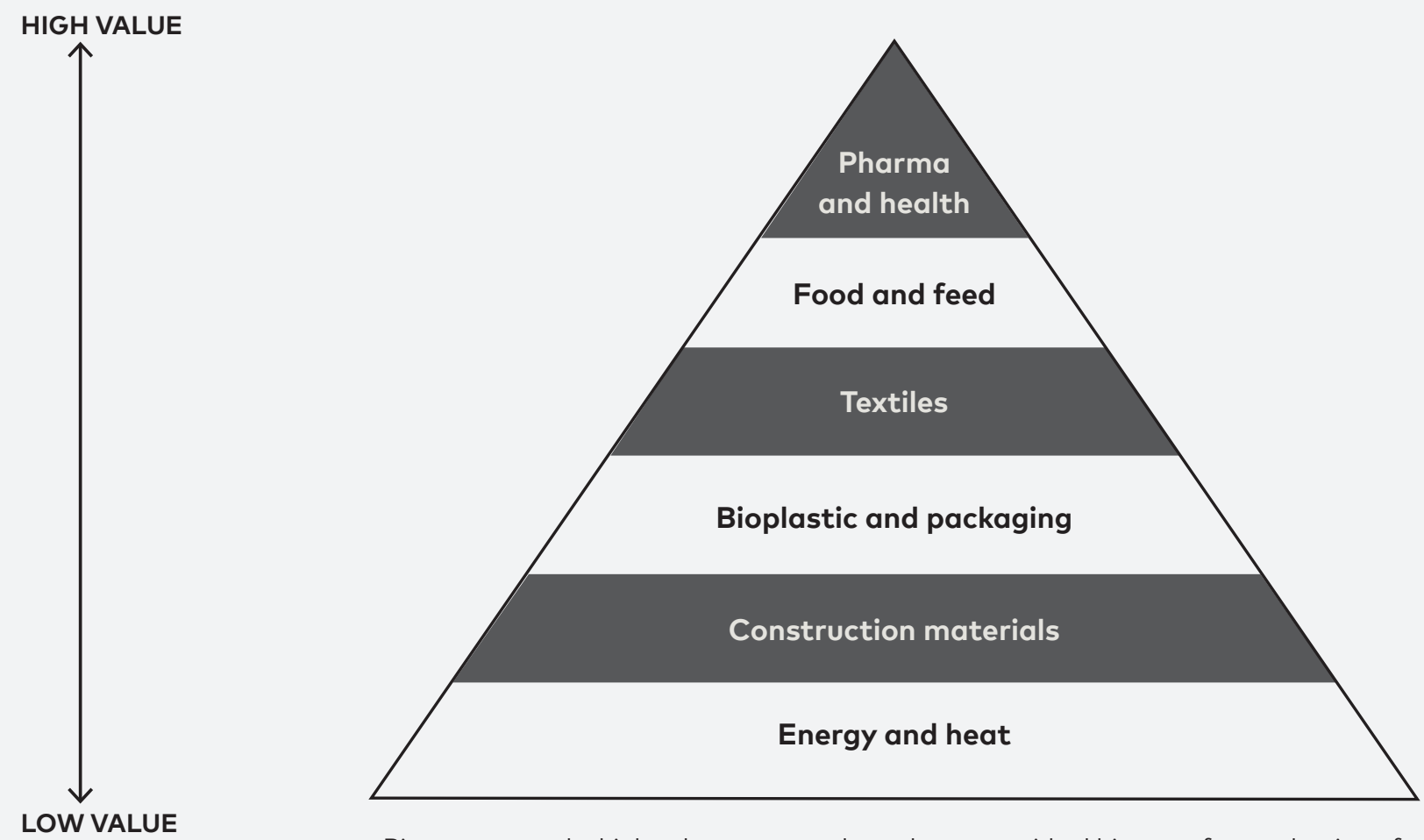

Biomass cascade: high value compounds at the top, residual biomass for production of low value energy, electricity and heat at the bottom.

\section{Sustainability}

In 2015 the Nordic Bioeconomy Panel was established with the mandate to develop a proposal and submit it to the Nordic Council of Ministers on a joint Nordic bioeconomy strategy designed to stimulate innovation and support a sustainable transition in the Nordic bioeconomy. The strategy will be launched in the end of 2017.

As a stepping-stone towards a sustainable bioeconomy, the Nordic Council of Ministers and the Nordic Bioeconomy Panel have collaborated with the Danish think-tank Sustainia (Monday Morning) on the development of a set of holistic yet tangible criteria for a sustainable bioeconomy - the Nordic bioeconomy.

It is with great anticipation that we present the following framework, knowing full well that there are other solutions out there. Nonetheless, it is our firm conviction that we need to push for clear and consistent targets and indicators to manage the green transition in our economy. Consequently, we have selected the following five criteria for a sustainable and innovative bioeconomy.
1.

SUSTAINABLE USE OF NATURAL RESOURCES

2. TECHNOLOGICAL INNOVATION

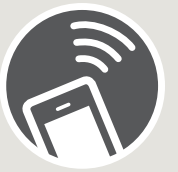

3. ENVIRONMENTAL BENEFITS

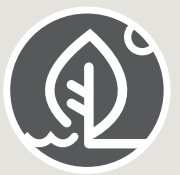

4.

SOCIETAL BENEFITS

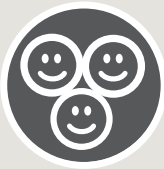

5.

BUSINESS MODEL INNOVATION

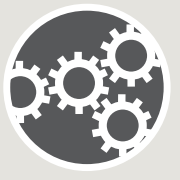

Criteria for a sustainable and innovative bioeconomy. 
The catalogue consists of 25 cases, evaluated on the basis of underlying questions and assessment parameters for each criterion. The framework for the evaluation is elaborated upon in chapter two.

\section{Nordic bioeconomy}

The 25 cases are grouped according to four "strongholds" (position of strengths) of the 'new' Nordic bioeconomy. In other words, the cases are examples of Nordic solutions to global challenges, based on a vision of a smarter, more sustainable and more inclusive society, focusing on the following four pillars: replace, upgrade, circulate and collaborate.

Together, the four pillars describe the direction in which all sectors of the bioeconomy need to move
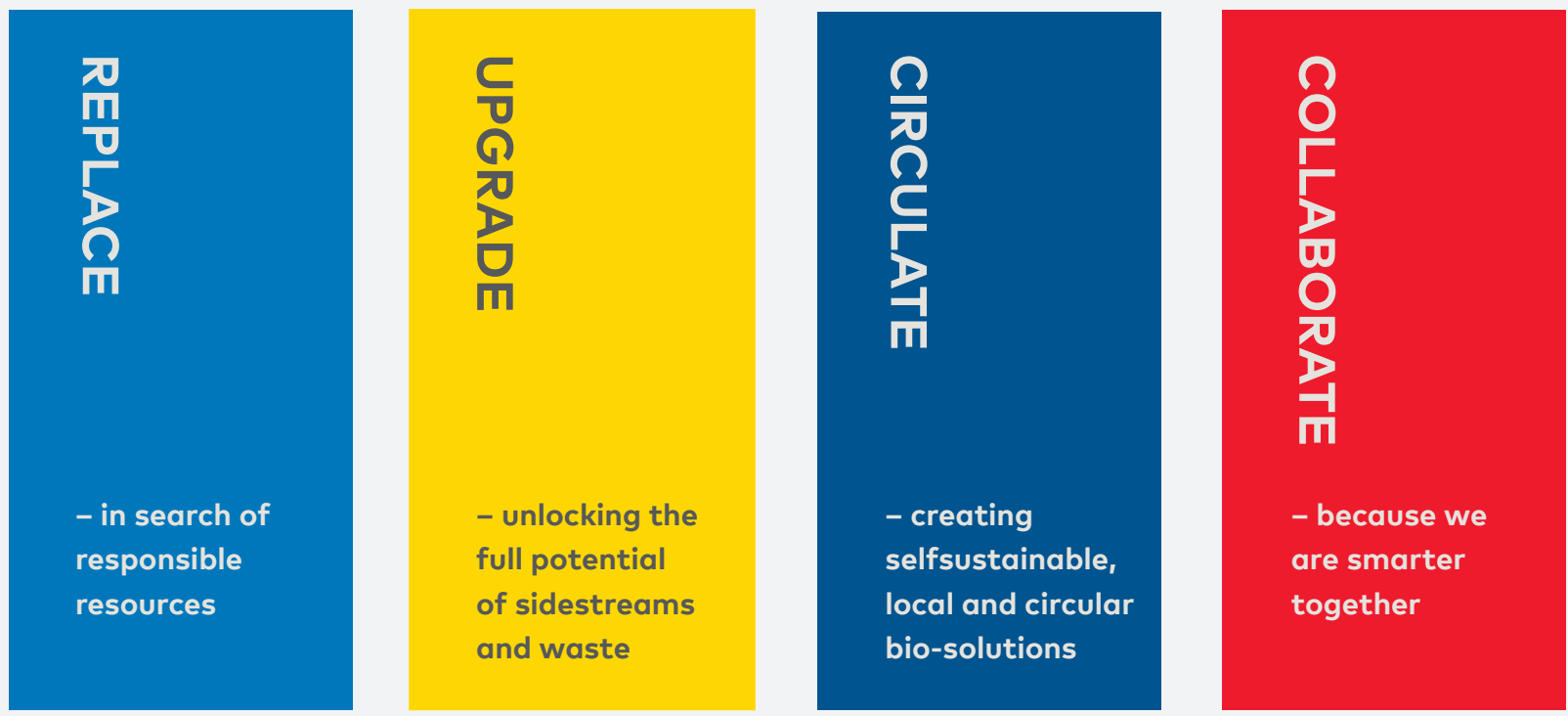

in order to realise sustainable production and consumption of our biological resources - from land and sea, from plants and farm animals. The aim is to showcase the diversity of the 'new' Nordic bioeconomy by including cases from different sectors, actors and areas in the Region. The cases range from some of the largest Nordic companies and clusters to small and medium-size startups, from universities to local authorities, and from capital cities to peripheral regions.

Our strong Nordic visions and national ambitions, along with examples of good practice, will help guide our efforts to achieve the 17 global sustainable development goals. We hope the 25 cases will pave the way for further sustainable development.

Strongholds of the Nordic bioeconomy. 


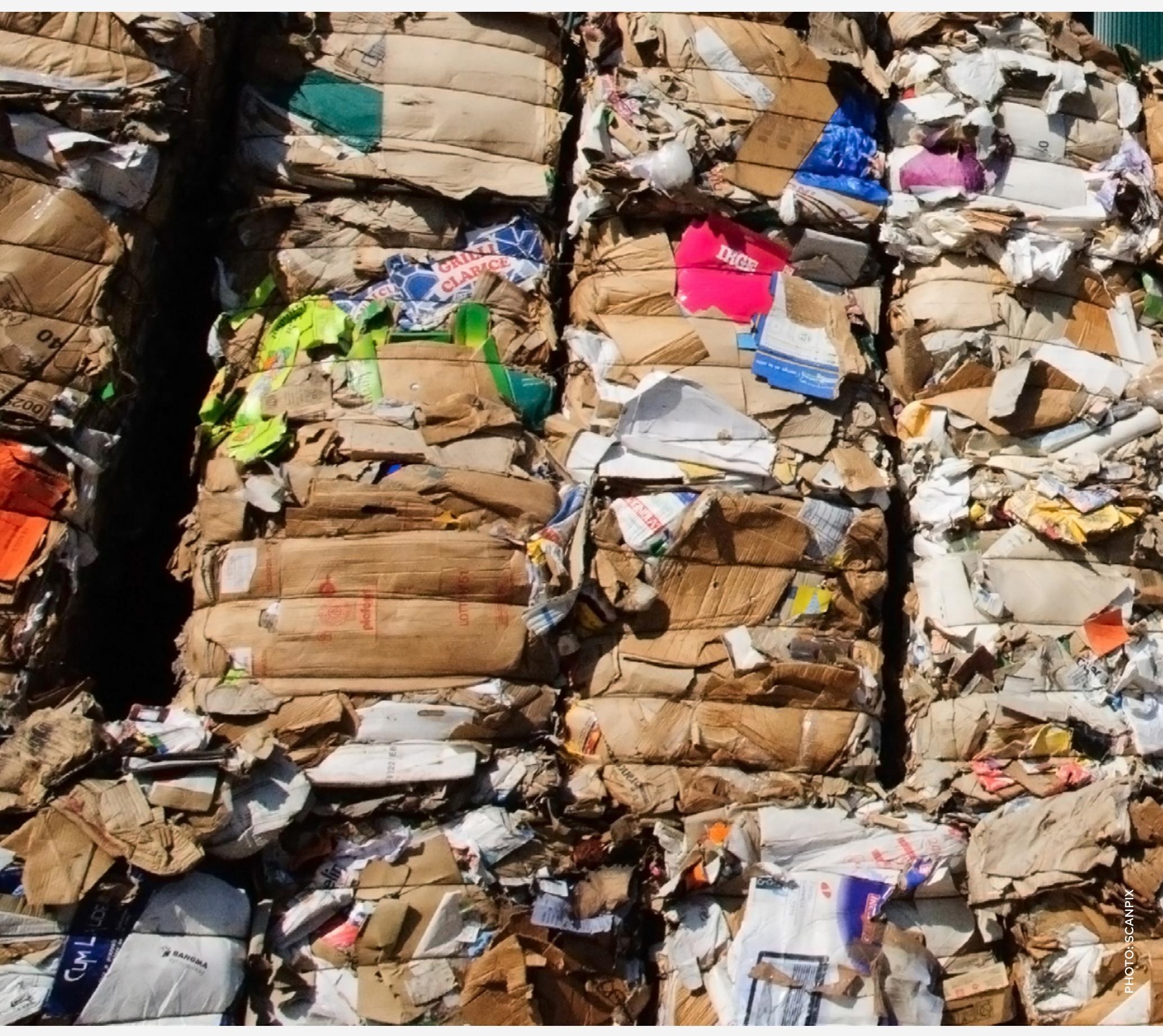




\section{Criteria for the Nordic bioeconomy}

This chapter describes the background and process behind the new attempt by the Nordic Council of Ministers to specify what the 'new' Nordic bioeconomy is. The Nordic Council of Ministers and the Nordic Bioeconomy Panel collaborated with the Danish think tank and consultancy Sustainia to develop five criteria on what constitutes a sustainable Nordic bioeconomy case and accordingly what information is necessary to assess and properly describe a good or best case.

Based on the above efforts, the Nordic Council of Ministers developed a project description template that applicants for this case catalogue were asked to complete as part of the application process. The template consists of five criteria with a related set of questions on what a good bioeconomy project or business model should live up to fully or partially.

The Nordic Council of Ministers and the Nordic Bioeconomy Panel wish to state that the criteria should be seen as work in progress and non-exhaustive. However, the criteria do provide an excellent starting point to access the different elements in the diverse variety of Nordic bioeconomy cases and on how to structure a case description. In the textboxes you will find the five criteria and related assessment parameters that were used to evaluate the applications.

\section{Criteria 1: Sustainable use of natural resources \\ Criteria 2: Technology innovation \\ Criteria 3: Environmental benefits \\ Criteria 4: Societal benefits \\ Criteria 5: Business model innovation}

\section{CRITERIA 1}

Sustainable use of natural resources

$\checkmark \quad$ Whether the case addresses issues of resource scarcity in the local context

$\checkmark$ The extent to which the case optimises the use of biomass

$\checkmark$ The extent to which the case contributes to a circular economy

\section{CRITERIA 2}

Technology innovation

$\checkmark$ The extent to which new technology is developed or applied

$\checkmark$ The extent to which existing technology is adapted to new applications

\section{CRITERIA 3}

Environmental benefits

$\checkmark$ The extent to which the case has already or has the potential to reduce $\mathrm{CO}_{2}$ emissions across the value chain; this relates both to direct reduced $\mathrm{CO}_{2}$ emissions (including substituting fossils with e.g. renewable energy) and getting more value out of the biomass already produced

$\checkmark$ The extent to which the case has the potential to improve ecosystems (by addressing issues such as air quality, water quality, biodiversity, etc.) 


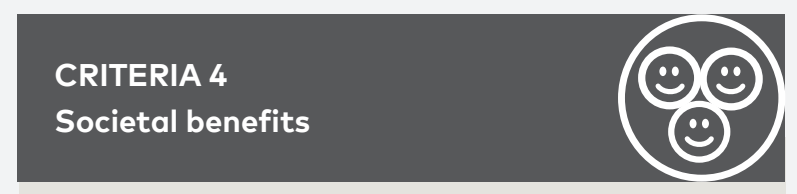

$\checkmark$ The extent to which the case has the potential to create new jobs

$\checkmark$ The extent to which the case engages local communities

$\checkmark$ The extent to which the case has the potential to provide positive public health or well-being benefit

\section{CRITERIA 5}

Business model innovation

$\checkmark$ The extent to which the business model involves new products or services

$\checkmark$ The extent to which the business model involves new cost structures or revenue streams

$\checkmark$ Whether the case has the potential to enter or create a new market(s)

\section{Evaluating the cases and future perspectives}

The evaluation criteria provided the framework for the Nordic Bioeconomy Panel to evaluate the cases in co-operation with the Nordic Council of Ministers and Sustainia, where all expert members received the cases and had the opportunity to provide input. The process and framework enabled the panel to select 25 cases that performed well overall on the evaluation criteria.

During the process of creating an assessment framework, the Nordic Council of Ministers and Sustainia experienced great progress in developing and deriving qualitative criteria to assess the quality of the bioeconomy cases. Although the submitted cases are very different in scope and sector, the process shows that common criteria can indeed be used for assessing the quality of a specific case. The nascent assessment system still needs to be refined, but can serve as a point of departure for future work in this area. Building upon these criteria quantitative indicators can also be developed to enable impact measurements and benchmarking between similar bioeconomy cases. This can potentially feed into a new paradigm of international standards and definitions on what constitutes a sustainable bioeconomy and a good bioeconomy case.

DISCLAIMER: The applications have been assessed and the cases written based on the submitted information. The information featured in this case catalogue is correct to the best of our knowledge and based on research as well as information and clarifications provided by the applying organisations and companies. 

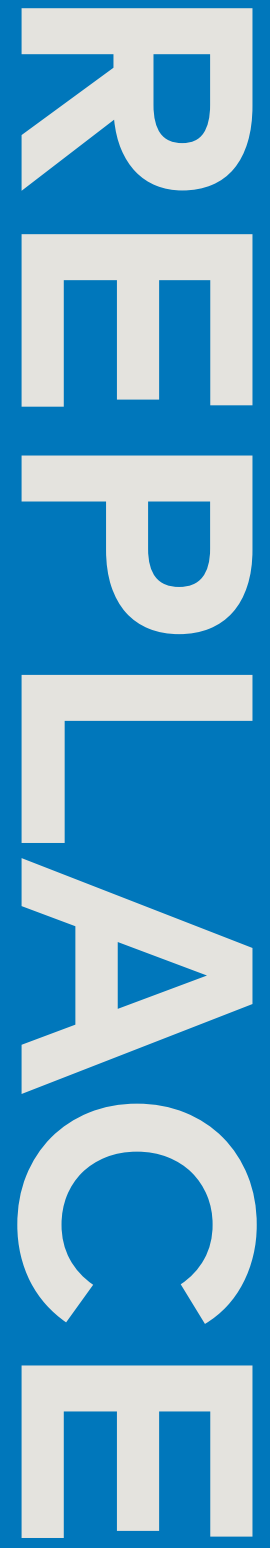


\title{
REPLACE \\ - in search of responsible resources
}

The current economic system facilitates substantial socio-economic development, but often at a price - namely, escalating resource use, environmental degradation and extensive climate impact. Bioeconomy refers to an economy based on plant-and animal-based resources (bio-resources). As such, it has the potential to fundamentally alter the way in which the global economy functions by replacing unsustainable, often fossil-based materials with bio-based materials from forest, farmland, marine plants, etc. When produced in a sustainable manner, these materials have many beneficial effects, including carbon capture through excess photosynthesis, curtailing erosion, protecting the soil, providing habitats for wildlife and many other ecosystem services.

Globally, the most common replacement strategy has been to substitute fossil-based energy and fuels with energy from biomass and bio-based fuels. However, this kind of one-for-one replacement is hardly optimal, since the energy market is relatively low-value, and bio-based fuels for transportation still depend on government subsidies in order to compete with fossil-based alternatives. In addition, using farmland for biofuel crops limits food and feed production. The Nordic Region has great potential in terms of replacing fossil-based and artificial resources with bio-based and natural resources, not least due to the vast areas in which biomass is found, e.g. seas and forests. The Region also has strong traditions of using bio-based production for much more than just food and feed - we build wooden houses, we are renowned for our wooden furniture, and we are exploring ways of producing sustainable textiles from wood residues, and new food and feed products from agricultural sidestreams and seaweed.

\author{
The Nordic Region has great \\ potential in terms of replacing \\ fossil-based and artificial \\ resources with bio-based and \\ natural resources, not least \\ due to the vast areas in which \\ biomass is found, e.g. seas \\ and forests.
}




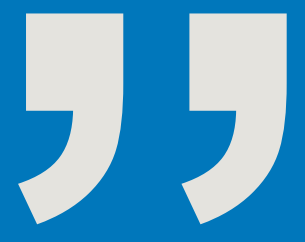

Wood-based

solutions in

construction

can lower $\mathrm{CO}_{2}$

emissions by

$50 \%$ 


\title{
Sustainable building solutions
}

\author{
Trefokus / Norway
}

Using a network-based approach, Trefokus connects a wide range of stakeholders in the building sector to increase the use of wood in construction. Trefokus uses a broad approach in which interaction with local communities, municipal planning processes, public procurement, interaction with building projects, education, and development of competencies all play a crucial role.

The Nardo School, in Norway, is an example of a project in which Trefokus began by cooperating with the local municipality to obtain support for using wood in public buildings. The process continued with R\&D support from Treteknisk/Tresenteret (sister organizations) and guidance to architects and entrepreneurs throughout the application process as well as during construction. The Nardo School project made use of wood, not only in the interiors but also in sheathing and even the load-bearing structures. Trefokus also works on small-scale projects such as Woody 35, an energy-efficient family house, which uses less building materials than conventional approaches to residential construction. The wood in Trefokus' projects comes from certified forests. Trefokus' ultimate aim is to enable mass-production of building materials and buildings made from wood.

\section{CRITERIA 3 \\ Environmental benefits}

According to Trefokus, wood-based solutions in construction can lower $\mathrm{CO}_{2}$ emissions by $50 \%$ compared to other building materials.

\section{CRITERIA 4}

Societal benefits

Trefokus engages teachers and schools to inspire youth to think of sustainable solutions in the building sector.

\section{CRITERIA 5}

Business model innovation

Trefokus inspires stakeholders to create a new market for wood-based building solutions in large-scale construction and urban environments. 


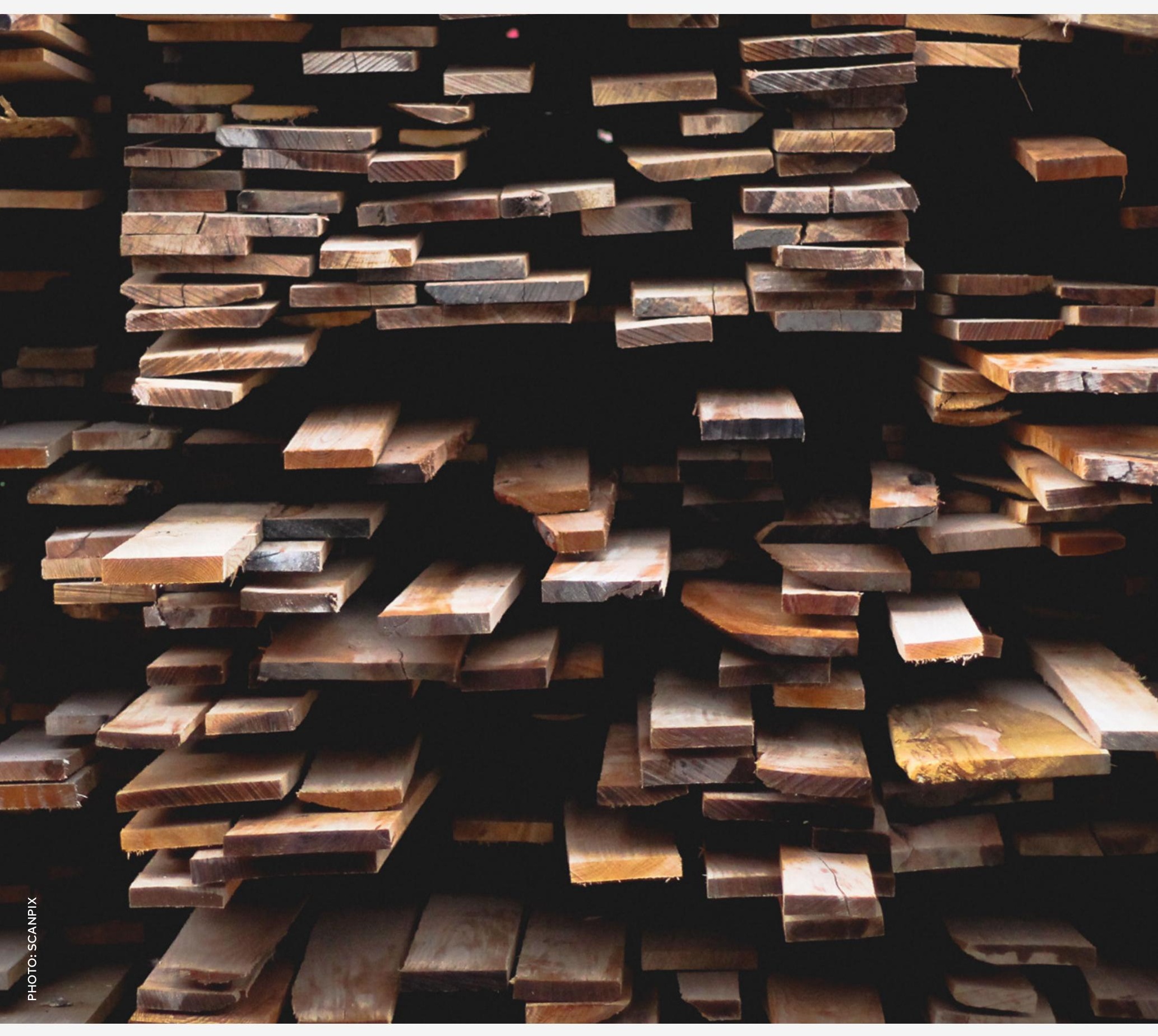




\section{From petroleum-based to bio-based additives}

\section{Borregaard / Norway}

The Exilva plant is a wood-based performance-enhancer that replaces petroleum-based additives in adhesives, coatings, agricultural chemicals, and cosmetics with bio-based materials - namely cellulose from wood, the most abundant organic polymer on Earth. Exilva consists of a network of suspended microfibers known as microfibrillated cellulose that are extracted from wood and converted into a network of microfibrils. It is a socalled multifunctional additive, which reinforces and stabilises various substances.

The production runs on renewable energy, and Exilva thereby not only improves the environmental performance of its products (in the shift from petrochemicals to wood), but also the process. To document this, Borregaard has since 2008 used an independent third party to conduct lifecycle studies of its activities, showing that the environmental and climate footprint of Borregaard's products has decreased. According to Borregaard, it also provides a better cost-efficiency ratio, good stability, and improved behaviour of the various final products it is being used for. The product is robust and versatile, enabling easy application to existing production lines. Microfibrillated cellulose was not available in commercial quantities until the opening of Borregaard's Exilva plant in 2016, with a production capacity of 1,000 tonnes per year.

\section{CRITERIA 3 \\ Environmental benefits}

Exilva is made from $100 \%$ natural raw materials that are sustainably sourced from Scandinavian forests.

\section{CRITERIA 4}

Societal benefits

The Exilva project at Borregaard is estimated to create around 50 full-time positions.

\section{CRITERIA 5}

\section{Business model innovation}

The ability to have a natural and highly sustainable additive with high performance as a substitute to petrochemical-based synthetic alternatives is quite new and can potentially open new markets.

\section{REPLACE}




\title{
Wood-based pharmaceuticals
}

\author{
UPM Biochemicals / Finland
}

GrowDex ${ }^{\circledast}$ is a wood nanocellulose hydrogel product developed by UPM-Kymmene Corporation for the needs of the pharmaceutical industry. GrowDex ${ }^{\circledR}$ is suitable for various cell culture purposes, and the material is biocompatible with human cells and tissues. These properties enable wide use in biomedical and pharmaceutical research and drug development applications. GrowDex ${ }^{\oplus}$ facilitates the growth of cells in a 3D environment, which mimics more closely natural tissues and organs compared to cells grown in 2D. GrowDex ${ }^{\circledR}$ can be used to replace animal testing and enable the development of cell-based drugs, tests, and models that can be used in the future to better treat serious diseases.

The wood-based GrowDex ${ }^{\oplus}$ hydrogel can replace synthetic and animal-based materials that are the industry standards. In many cases, GrowDex ${ }^{\oplus}$ can be disposed of via normal waste channels, unlike animal-based alternatives that are classified as hazardous waste. The product can be stored at room temperature conditions, so the product has more suitable storage properties compared to animal-based alternatives, which perish at room temperature.

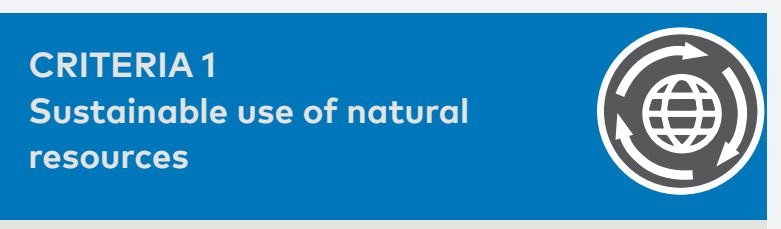

GrowDex ${ }^{\circledast}$ represents a new utilisation area for wood pulp by replacing synthetic and animal-derived materials in the pharmaceutical industry.

\section{CRITERIA 4}

Societal benefits

With the development and commercialisation of GrowDex ${ }^{\oplus}$, UPM provides direct and indirect job opportunities for hundreds of people, and creates possibilities to better treat serious diseases in the future.

\section{CRITERIA 5}

Business model innovation

Traditionally, wood pulp producers have mainly delivered material to the paper industry, so GrowDex ${ }^{\circledast}$ opens new business opportunities for UPM as well as for other SME companies operating in the pharmaceutical industry. 


\title{
Renewable diesel from wood
}

\author{
UPM Biofuels / Finland
}

UPM Biofuels has developed a process to transform wood-based residues from pulp production into an advanced biofuel that can be used in any diesel engine without modification. The product, UPM BioVerno, is a commercial-scale renewable diesel that reduces greenhouse gas emissions as well as tailpipe emissions significantly compared to conventional fossil diesel. UPM Biofuels uses a hydrotreating process provided by Haldor Topsøe to produce the biofuel. Production of the renewable diesel does not generate additional demand for forest harvest areas or compete with food production as processing residues are used as feedstock.

UPM Biofuels established the first commercial-scale wood-based biorefinery in the world. It is located in Lappeenranta, Finland, and started production, in January 2015, with an annual production capacity of 120 million litres of renewable diesel. This is enough diesel for around 100,000 cars per year.

CRITERIA 1

Sustainable use of natural

resources

By processing crude tall oil, a residue from pulp production, UPM Biofuels is able to utilise the wood used for its pulp production in a more efficient way without increasing wood harvesting or land use.

\section{CRITERIA 3}

Environmental benefits

When UPM BioVerno is used by vehicles as a replacement for fossil diesel, it reduces $\mathrm{CO}_{2}$ emissions by around 250,000 tonnes annually, according to the company.

\section{CRITERIA 5}

Business model innovation

UPM Biofuels has traditionally been a forest products company, but has entered new markets with the production of UPM BioVerno diesel. 


\title{
Fish feed from seaweed
}

\author{
BlueGreenFuture / Faroe Islands
}

BlueGreenFuture aims to develop a functional blue biorefinery, which will produce industrial and consumer commodities from sustainable cultivated seaweed. The seaweed products could be used as partial replacement for many artificial ingredients in fish feed such as proteins, oils, vitamin and mineral mixes, binders, antibiotics, antioxidants, and colorants. Furthermore, the residuals from the biorefinery process can be used as fertilisers and for bioenergy conversion, which ensures a $100 \%$ utilisation of the seaweed biomass. Currently, most of the world's industrial biomass is created on land. The solution can free valuable land for other uses, while the seaweed cultivation also has beneficial outcomes for the environment. For example, annual cultivation of 500 tonnes of seaweed plants on less than $1 \mathrm{~km}^{2}$ extracts excess nutrients consisting of 2.5 tonnes of nitrogen and $150 \mathrm{~kg}$ of phosphorus.

BlueGreenFuture uses seaweed biomass that does not compete directly or indirectly with other feedstock resources, such as those utilised for food or feed production. The extraction and purification processes are based on research and development that have been tested and used in laboratories, but BlueGreenFuture claims to be the first company to implement them on a commercial scale.

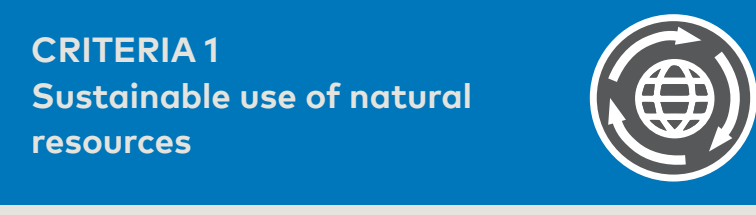

BlueGreenFuture creates more sustainable biomass feedstock by expanding the current biomass portfolio through use of seaweed. In this way, the use of land and fresh water are minimised.

\section{CRITERIA 3}

Environmental benefits

Full industrial ramp-up of the biorefinery to 10,000 tonnes of seaweed will sequester 4,300 tonnes of $\mathrm{CO}_{2}$, equivalent to the emissions from 2,600 households.

\section{CRITERIA 4}

Societal benefits

The success of BlueGreenFuture is expected to lead to an industrial ramp-up and an estimated continual employment of 30 people in rural areas. 
$\cos ^{2}+x^{2}=$

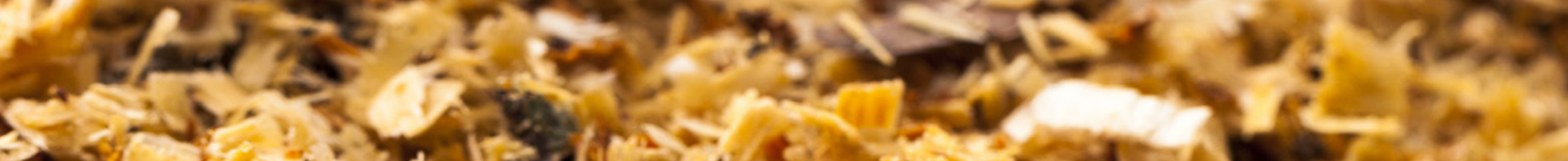

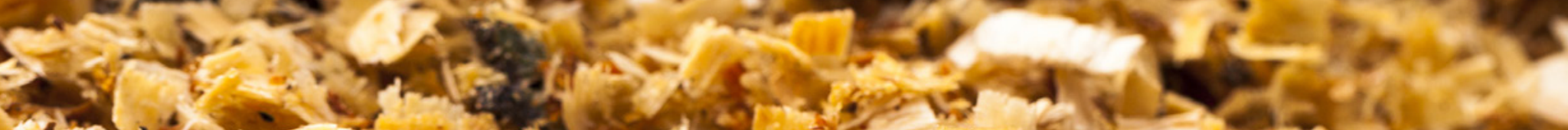

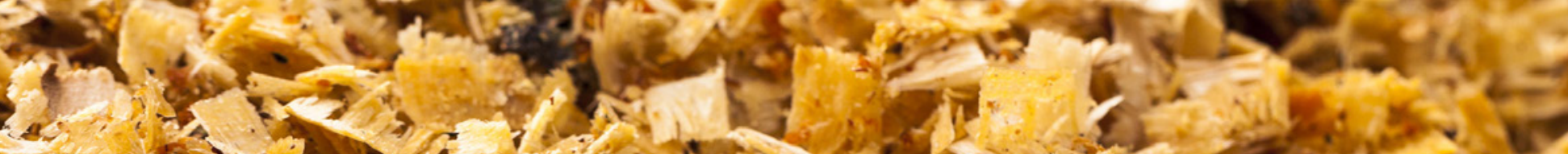

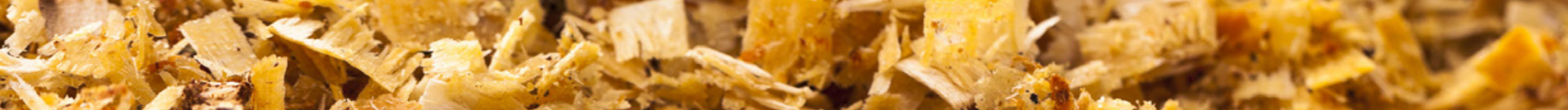

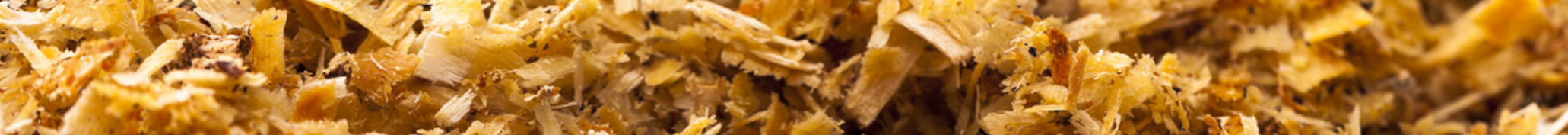

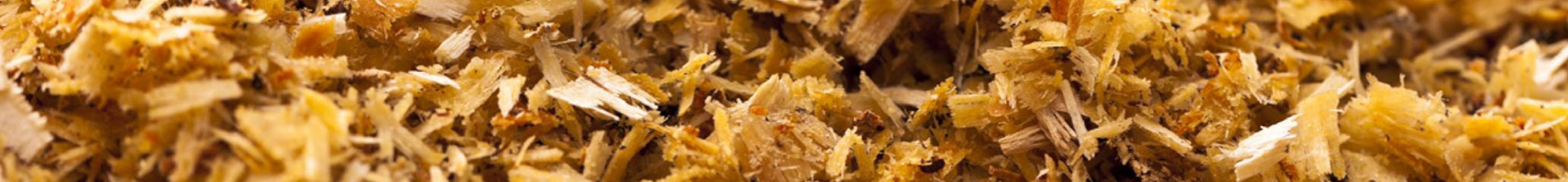

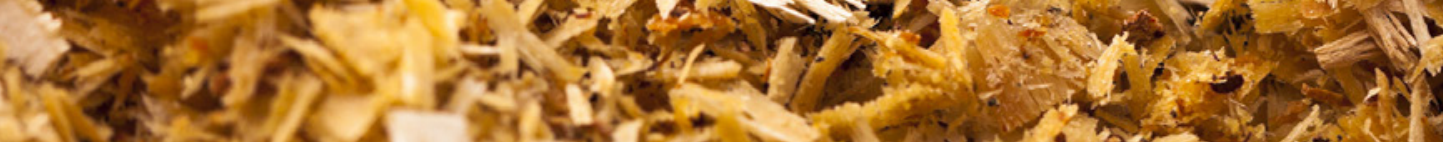

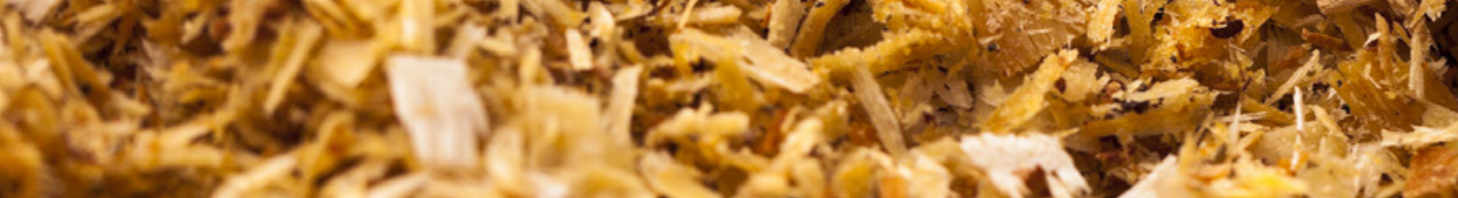
t.

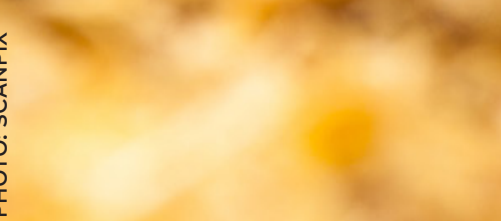




\section{Fly away on wood pulp}

Innventia / Sweden

The LignoJet project showcases how jet fuel can be produced from forest raw materials that do not compete with food production. LignoJet is a Swedish-Brazilian collaboration based on the use of lignin, which was formerly considered a paper and pulp industry byproduct, as the raw material for bio-based jet fuel. Lignin is a class of complex organic polymers that form important structural materials in the support tissues of vascular plants and some algae. It is one of the most abundant organic polymers on Earth, constituting $30 \%$ of non-fossil organic carbon, exceeded only by cellulose.

Brazil and Sweden are well-equipped to help address these challenges, as they are two of the world's leading producers of wood pulp and maintain substantial knowledge and expertise in the use of wood as a raw material for various purposes. The project includes a broad range of stakeholders along the value chain, including Brazilian pulp producers and a Swedish airport, to successfully introduce LignoJet to the market. Preliminary results of the first phase are very promising, and initiatives for scaling-up production are in progress. Additionally, continued work focuses on identifying valuable components in the product stream and supporting a good overall process economy through co-production of chemicals and fuels.

\section{CRITERIA 1 \\ Sustainable use of natural \\ resources}

LignoJet is produced through integrated production in the pulp mill, making biofuel out of what was formerly considered a byproduct, and the production therefore does not compete with food production.

\section{CRITERIA 3}

Environmental benefits

The long-term production potential of lignin in Sweden and Brazil alone is estimated at 12 million tonnes per year. Processing this for biofuel can potentially reduce fossil fuel emissions by 20 million tonnes $\mathrm{CO}_{2}$ annually.

\section{CRITERIA 5}

Business model innovation

LignoJet strives to keep productions costs low as they integrate production in the pulp mill where the processes and equipment to handle large flows cost effectively are already present.

\section{REPLACE}





\section{Outro}

The six cases demonstrate how bio-based products and services have a broad range of applications and can replace environmentally harmful fossil-based products and services. The breadth of the solutions underlines the versatility of wood as a material. Aside from traditional uses such as construction materials, wood can also be broken down and exploited for its chemical properties. Cellulose and lignin are amongst the most abundant organic polymers on the planet, and therefore have great potential.

Many of the projects presented are still under development or being refined, and a common challenge is, therefore, to convince the various stakeholders in the value chain that the new wood-based or sea-based products are competitive and a true alternative to their existing competitors. A further concern is whether the demand for wood-based products will result in the use of arable land that would otherwise have been used for food production. However, in many of the cases, residuals previously regarded as waste are used as feedstock, which brings current production facilities closer to a circular model capable of serving as a source of inspiration for other Nordic companies.

\section{Aside from traditional uses such as construction materials, wood can also be broken down and exploited for its chemical properties.}



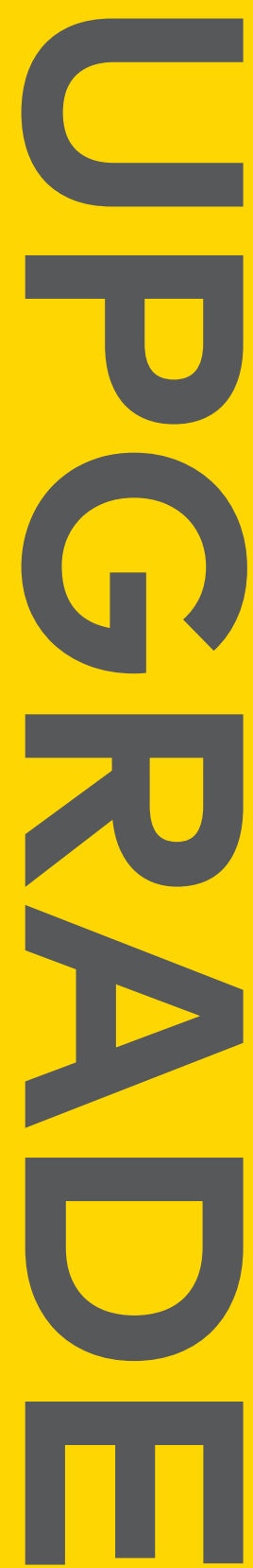


\section{UPGRADE \\ - unlocking the full potential of sidestreams and waste}

Upgrading is vital for realising the full potential of the Nordic bioeconomy. Upgrading refers to optimisation throughout the whole value chain, and an emphasis on higher value products and services. The Nordic bioeconomies have focused on increasing the value of currently unused and underutilised living natural resources, as well as on unlocking the full potential of residues and waste. The key elements in achieving this are education, research, development and innovation, biotechnology, digitalisation, biorefineries, infrastructure, and financing.

One of the main global societal challenges is the wasteful and unsustainable practices involved in utilising living natural resources, both terrestrial and aquatic. The sub-optimal use of natural resources results in huge economic, social and environmental waste - and this inefficiency needs to be addressed as a matter of urgency. Quite rightly, efforts have been made to highlight the role of consumers in combating food waste, but this is only part of the problem. Inefficiency permeates the entire value chain - sometimes as much in production as in consumption. Reducing this inefficiency is crucial to the health of our ecosystems, the wellbeing of our rural and coastal communities, and the survival of our bioeconomy industries.

By focusing on innovation in the development and marketing of products and services that yield the greatest benefits, the efficiency of our resource use increases and the environmental and carbon footprint decreases. The Nordic bioeconomies have an opportunity to be at the forefront of utilising the full potential of raw materials that are caught and harvested. Here is a small selection of the many inspirational Nordic success stories.

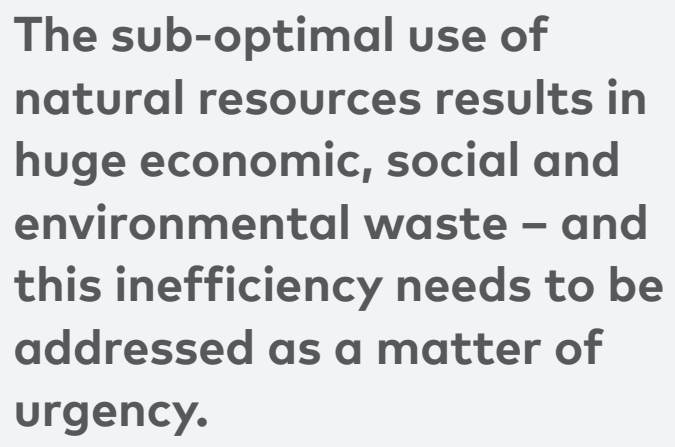




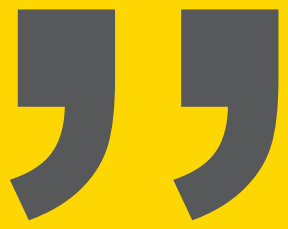

The value of

the cod skin will

be increased by

$300 \%$ from the

current low

value 


\title{
Maximum value from every part of the cod
}

\author{
Codland / Iceland
}

The aim of Codland is to develop valuable new products from parts of the cod that were previously been regarded as waste and to increase the utilisation and value of each fish caught from the limited stocks of cod around Iceland. Codland was founded by a number of well-established fisheries, and is engaged in interdisciplinary collaboration between academia, research institutions, and other fisheries to reach its goals.

Codland focuses on developing facilities capable of refining valuable products from underutilised raw materials from whitefish fisheries. The company is setting up facilities making it possible to produce nutraceutical supplements from the fish skin, cod oil from the liver, and crude oil and feed from the viscera. By converting innards into fish oil, and fish skin into collagen peptides, two underutilised and undervalued byproducts are converted into valuable products. Enzymes being developed for the production of collagen peptides aim to replace chemical methods.

The facilities are being built alongside an existing fish drying plant, enabling almost all fishery byproducts to be processed at one location and creating a closed-loop system to eliminate most of the waste streams. This is part of an ongoing effort to develop processes that ensure proper handling of byproducts throughout the value chain and optimise manufacturing.

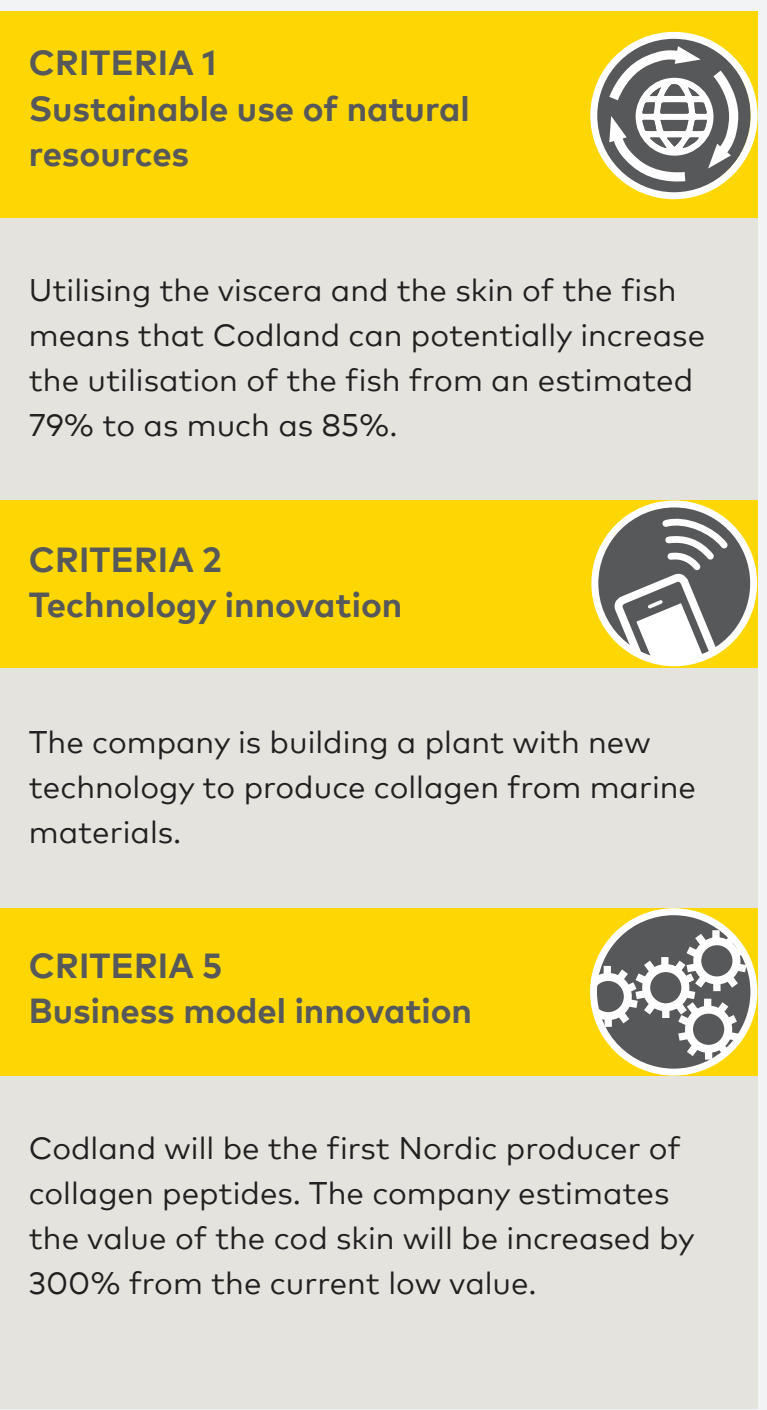




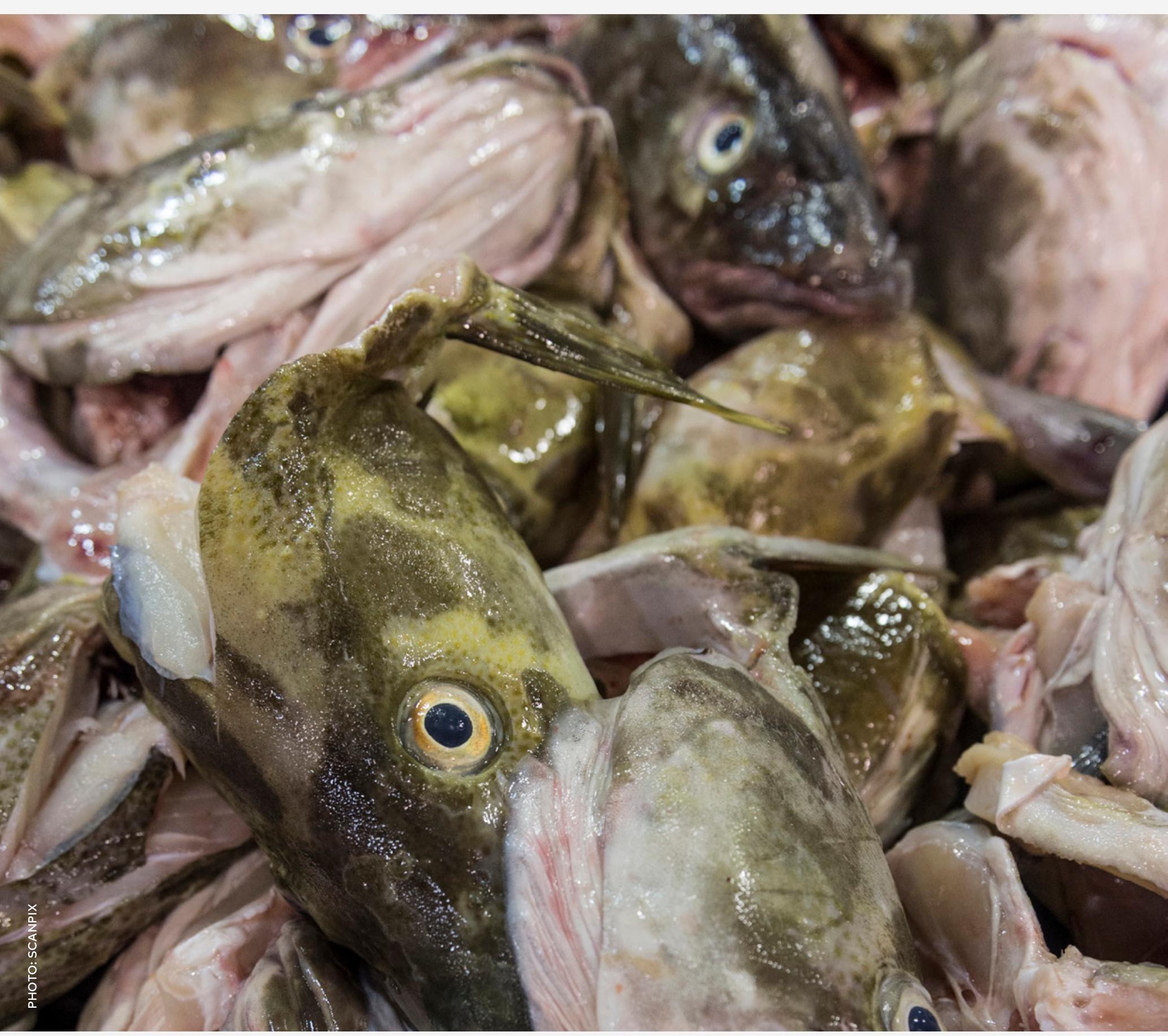




\title{
Using the whole fish: From 50 to $90 \%$
}

\author{
Polar Seafood / Greenland
}

Polar Seafood has changed its business model from previously only selling the filets of the Greenland halibut to also selling the heads, tails, and bones. An upgrade in machinery made it possible to process almost every part of the fish, increasing the utilisation rate from $50 \%$ to $90 \%$. Previously, the remaining $50 \%$ of the fish was thrown away, or in some cases used as dog feed. Now, Polar Seafood has managed to turn what was formerly regarded as an environmental burden into a profit-making product.

The company decided to invest in new machinery after intensive market research in Asia. By monitoring the markets for traditional fish diets, the company has successfully developed and encouraged a demand for the head, tail, and bones of the Greenland halibut. This means that Polar Seafood is now making a profit from all parts of the fish except for the skin.

\section{CRITERIA 1 \\ Sustainable use of natural resources}

Polar Seafood has gone from utilising $50 \%$ of the halibut to $90 \%$ by using all parts of the fish except the skin, thereby eliminating a big waste problem.

\section{CRITERIA 4 \\ Societal benefits}

The Greenland halibut fishery is the second biggest contributor to the country's economy, employing more than 900 people.

\section{CRITERIA 5 \\ Business model innovation}

Due to intensive market monitoring and a subsequent successful market development, the company now sells fish heads, tails, and bones to Asian markets, making profit out of former waste. 


\section{Turning tonnes of waste into new products}

\section{Biomega / Norway}

Biomega produces salmon oil, meal, and peptides for pet food and human consumption by sourcing more than 36,000 tonnes of former by-products such as heads, fins, bones, guts, and tails. For a long time, the non-edible parts of the fish were dumped into the sea, causing detrimental effects to ocean health. Now, the company sources these former waste products from slaughterhouses along the Norwegian coast. In doing so, Biomega reduces the slaughterhouses' waste disposal expenses and instead provides them with a new source of income.

The company's patented process uses natural enzymes to predigest proteins, emulating digestive systems. The use of heat is kept to a minimum, and the process ensures the gentle separation of the nutritional components, preserving more nutrients such as proteins and minerals than chemical methods yield. Processing begins not more than two days after slaughter, and the salmon is kept refrigerated throughout the production process, enabling the meal, oil, and peptides to be certified and fit for human consumption. The company uses every part of the salmon except for the fillet, which is sold individually.

\section{CRITERIA 1 \\ Sustainable use of natural resources}

The continuous enzymatic hydrolysis process preserves more nutrients than chemical methods and utilizes $100 \%$ of the raw materials.

\section{CRITERIA 4 \\ Technology innovation}

The pre-digested proteins exhibit bioactive effects such as increased immune system stimulation, heart benefits, and improved intestinal health.

\section{CRITERIA 5 \\ Business model innovation}

Biomega spends a minimum of $8 \%$ of revenues on research and development to continuously improve the product range and processes. 


\title{
New nutrition supplements from slaughterhouse sidestreams
}

\author{
Danish Crown Ingredients / Denmark
}

Danish Crown Ingredients develops and produces new feed and food ingredients based on side streams from the many Danish Crown slaughterhouse operations. The ingredient company within the Danish Crown group started as a separate business unit in 2014 with the aim of using the side streams more efficiently and to generate business opportunities from new products and increase overall resource efficiency.

The development of a series of protein hydrolysates have especially proved valuable as ingredients in sausages and cured meat products, in sport nutrition products, and in special and senior nutrition products due to their high proportions of essential amino-acids. For the pharmaceutical industry, Danish Crown Ingredients has also developed blood-based products from the slaughterhouse side streams that can help treat iron deficiency. The side streams from meat production generally have very high potentials for being upgraded to products of high value as it only requires minimal extra water and energy. Furthermore the bloodbased products are a natural alternative that can replace iron supplements from chemicals and fossil-based products in the pharmaceutical industry.

CRITERIA 1
Sustainable use of natural
resources
350,000 tonnes of by-products are processed
and given a higher product value through
Danish Crown's new efforts.
CRITERIA 4
Societal benefits
Danish Crown Ingredients produces a series
of supplements that improve the uptake of
protein for use in sports, special and senior
nutrition, as well as the blood-based products
provides a natural alternative to help treat
iron deficiency.
The product innovations have enabled Dan-
ish Crown to enter new markets in form of
pharma compound materials and human and
animal nutrition supplements.
Business model innovation
CRITER




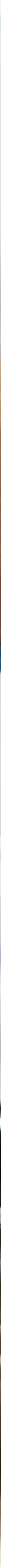




\title{
From waste shells to flour
}

\author{
Royal Greenland / Greenland
}

Royal Greenland produces flour from waste shells at their prawn factory in Ilulissat, Greenland. Waste shells from the cooking and processing of prawns had previously posed an environmental problem for the factory and the town it is located in as this material is permitted to be released into the sea. Royal Greenland has therefore produced meal for animal feed from the shells for some time, but lack of sufficient infrastructure, high energy prices, and expensive freight prices from Greenland to other markets has challenged the financial viability. With an upgrade of the prawn factory in Ilulissat, Royal Greenland is now able to transform the waste peels into flour fit for human consumption. In doing so, the company managed to double the utilisation rate of the shrimp and create a value-added product from a previous waste stream.

Royal Greenland has two cooking and peeling plants in Greenland, and is now focused on expanding the Ilulissat project. The company has also switched the power input at the llulissat plant from oil to electricity and hydropower. A recent MSC certification of the prawn fishery has contributed further to the value of the final product.

\section{CRITERIA 1 \\ Sustainable use of natural resources}

The factory upgrade enabled Royal Greenland to utilise the remaining part of the shrimp, which was formerly considered waste.

\section{CRITERIA 3 \\ Environmental benefits}

In Greenland, waste from fish and prawn production is permitted to be released into the sea. This approach reduces the risk of disturbing the balance in ocean ecosystems.

\section{CRITERIA 4}

Societal benefits

Royal Greenland expects to increase employment if the approach is expanded to other plants. 

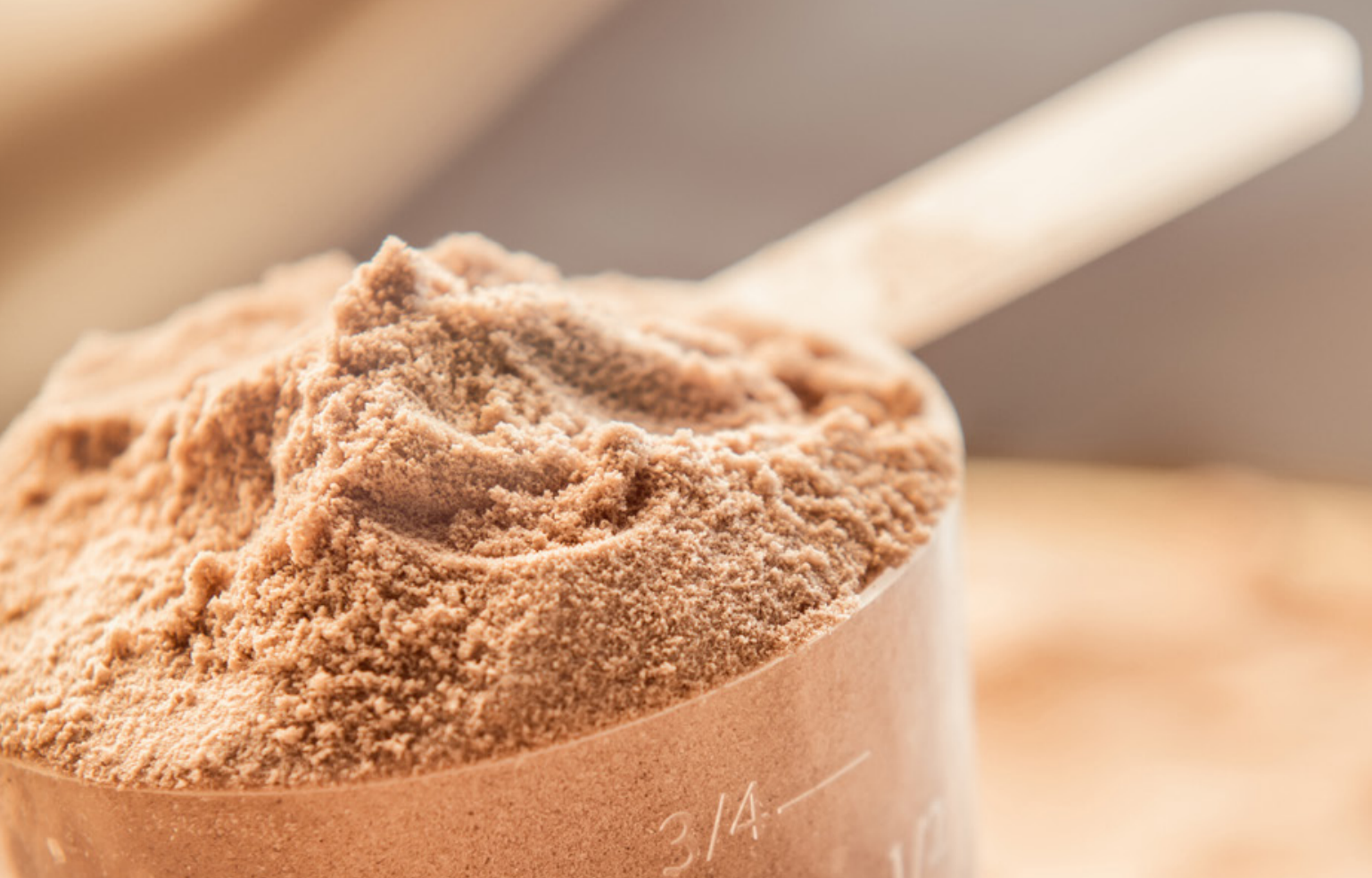


\section{Upgrading cheese-waste to protein powder}

\section{Arla / Denmark}

Arla has successfully converted whey from being a by-product from cheese production into a valuable ingredient in products such as protein powder. Previously, whey was sold as animal feed, but is now mainly sold for human consumption in the areas of medical, infant and sports nutrition due to its high content of proteins. As a result of strong market demand for whey-based products Arla is now importing about $50 \%$ of the raw material for whey protein as the company need more raw material than its own main production facilities can deliver.

Over the past two decades Arla has evolved into a modern biorefinery that use all components of its primary feedstock, milk, to create and commercialize a whole new value-chain of ingredients and products. These side stream-based products help Arla to unlock the full potential of the biomass and create new business opportunities from commercializing products on the basis of new consumer demands. The global market for the new products seems to keep growing. As an example, with an annual growth rate of $17 \%$ the last five years Arla now has a $20 \%$ market share of whey by-products.

\section{CRITERIA 1 \\ Sustainable use of natural resources}

Arla's biorefinery side stream processing is resource efficient and uses a minimum of electricity and water.

\section{CRITERIA 4}

Societal benefits

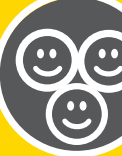

Arla estimates that around 300 jobs have been created from the new business model revolving around whey protein.

\section{CRITERIA 5}

Business model innovation

Arla has managed to unlock the full potential of their raw materials by turning a previously low-valued by-product into a new revenue stream. 


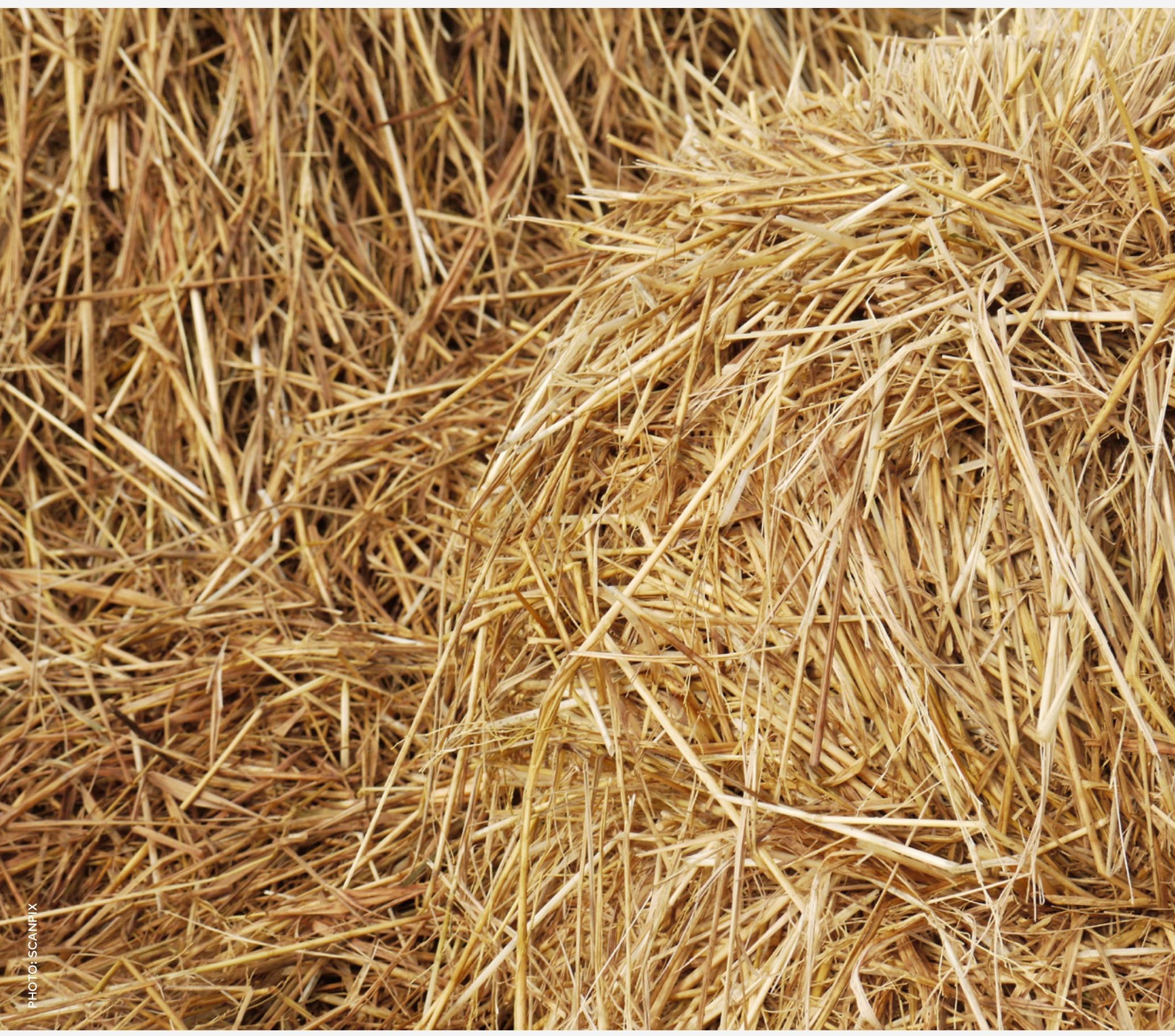




\title{
Upgrading plant materials to high-value products
}

\author{
BioValue SPIR / Denmark
}

BioValue SPIR is a strategic platform for innovation and research on value-added products from biomass. Sixteen private and public partners have used the platform to develop new solutions to upgrade plant material into high-value products, such as proteins, polymers, and other chemical components for the industry. Projects include development of robust biomass supply chains for biorefineries; development of optimised separation and conversion technologies into products such as protein-rich feed fractions, lysine from biomass sugars, and bio-based binders from lignin.

The projects on the platform address the entire value chain - from sustainable biomass production to improved separation and conversion techniques. Running from 2013 to 2018, the platform, which is jointly funded by the partners and Innovation Fund Denmark, has a budget of EUR 21 million to achieve its goal of developing internationally competitive products from biomass. The platform co-funds a number of projects to help small- and medium-sized enterprises in bringing innovations and products within biorefinery to the market.

\section{CRITERIA 1 \\ Sustainable use of natural resources}

BioValue aims to offer a more sustainable, locally grown protein source for animal feed to substitute part of the soy protein import. Through a cascading approach, the platform focuses on utilising and upgrading all plant components from biomass such as straw, leaves, and process side streams. A special analysis platform assesses sustainability of value chains and key technologies across the projects.

\section{CRITERIA 4 \\ Societal benefits}

Successful implementation of biorefinery technologies investigated in BioValue has the potential to create more than 20,000 jobs in Denmark.

\section{CRITERIA 5}

Business model innovation

The platform enables Danish companies to develop new products (binders), new technologies (in lysine production, separation techniques, conversion strategies and biomass-water interactions) or new services (e.g. advisory service on cost calculations). 


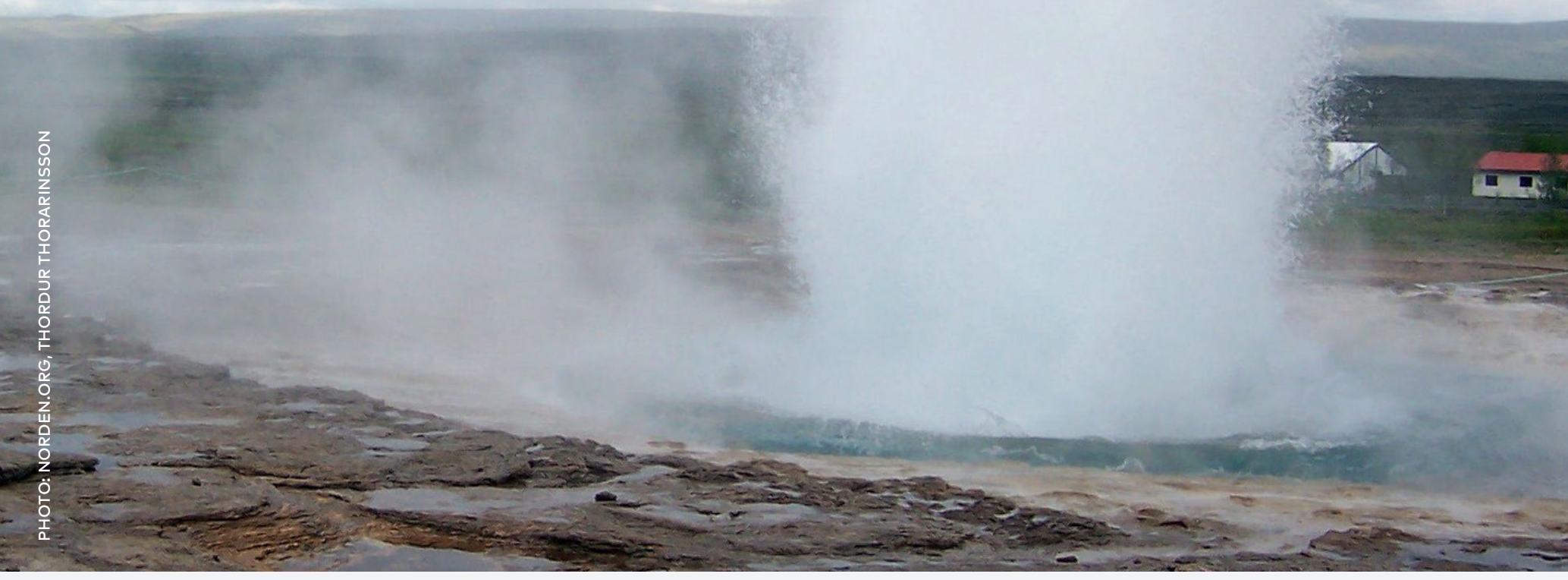




\section{Self-sufficient and sustainable farming}

Porvaldseyri / Iceland

Porvaldseyri aims to become a sustainable farm that adheres to circular economy principles. Porvaldseyri is a grain and dairy farm that produces its own feed as well as biofuel for tractors and other farm vehicles from hay, grain, and rapeseed. The farm sources hot water from a local borehole and electricity from a local hydropower plant. The farm is working to become self-sufficient in energy as well as in fertiliser for crop production, where manure and other by-products are used for onsite production.

Dorvaldseyri no longer has to buy fertiliser or grain for feed, reducing costs and cutting $\mathrm{CO}_{2}$ emissions by more than 18 tonnes per year. The farm also sells its crop to local bakeries and breweries that formerly had to import grain. The farm is located just below Eyjafjallajökull Glacier Volcano, which is known for an eruption that grounded thousands of planes in 2010. The ash damaged crops and killed livestock, but the community rose from the ashes. A visitors' center at the foot of the volcano now creates an extra source of income for the farm.

\section{CRITERIA 1 \\ Sustainable use of natural resources}

$100 \%$ of the farm's energy needs are covered by renewable hydropower supplied by a hydropower plant located on the premises and the national grind.

\section{CRITERIA 3 \\ Environmental benefits}

By working towards sustainability and farm optimisation, Dorvaldseyri saves an estimated 18 tonnes of $\mathrm{CO}_{2}$ annually.

\section{CRITERIA 5 \\ Business model innovation}

Porvaldseyri is exploring synergies between the bioeconomy and tourism as tourism is ideal for food products perceived to be uniquely Icelandic. 


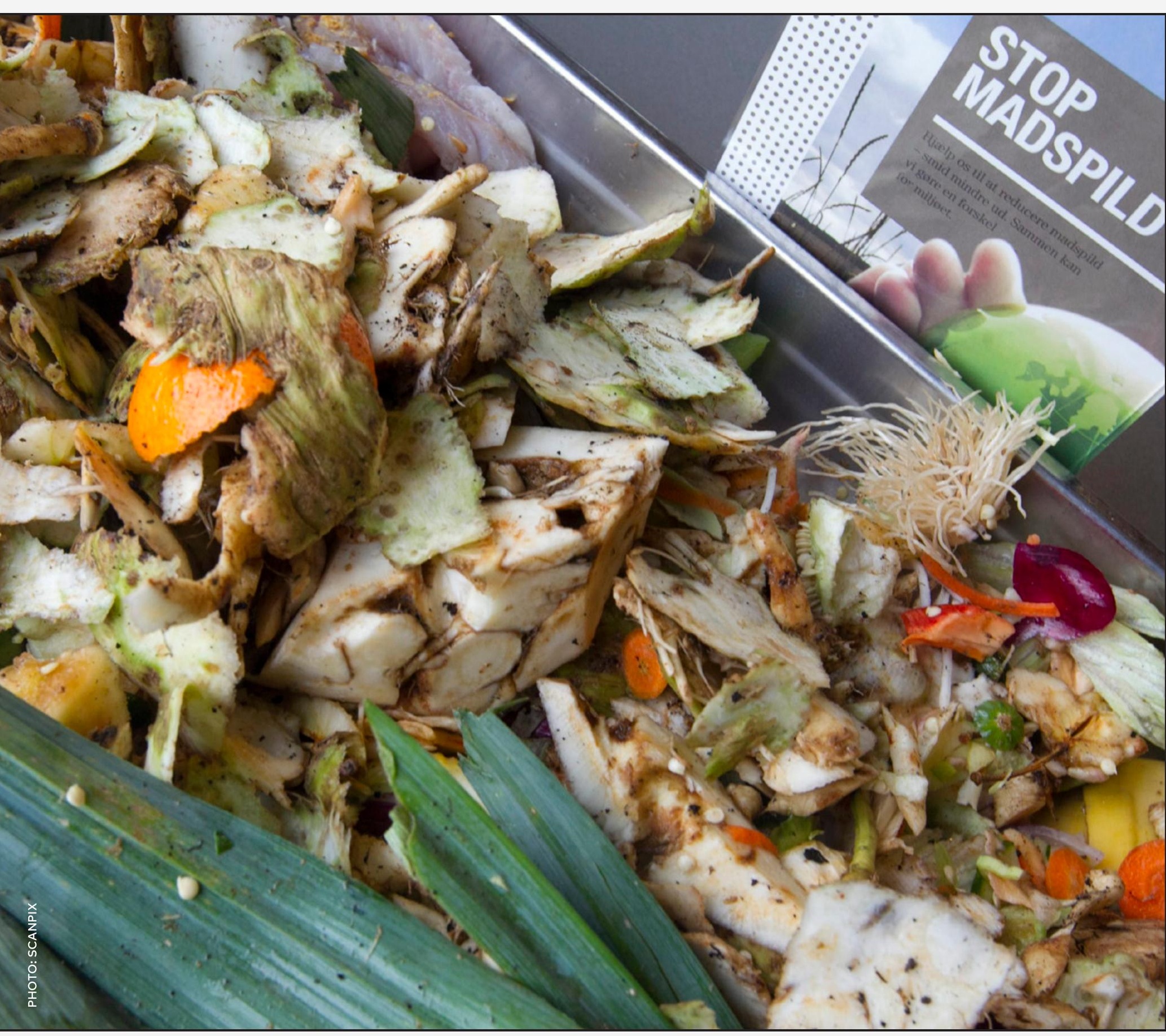




\title{
Turning waste into new products
}

\author{
DONG Energy / Denmark
}

By adding enzymes to residual waste at the processing plant, DONG Energy has invented a new method for separating organic waste from plastic, glass, and metals and upgrading the use of the organic fraction of household waste. DONG adds enzymes to the waste at the processing plant, which transforms the organic waste into a liquid, enabling efficient separation of the solids from the liquid. The separated liquid consisting of organic matter can be utilised for biogas, electricity, and heat. In this way, more household waste is upgraded to value-added products and metals and plastic are recycled. In the future, the technology, called REnescience, might also use the organic matter for production of organic acids that can be used in bioplastics. The technology was developed in Denmark and proven at a demonstration plant in Copenhagen.

A new full-scale plant utilising the separation method is expected to be operational in 2017 in Northwich, UK. The plant will treat 120,000 tonnes of residual waste per year, equivalent to the annual waste from approximately 110,000 UK households. The technology is continuously bebying refined and improved.

\section{CRITERIA 1 \\ Sustainable use of natural resources}

The high capture rates of the biodegradable waste enables more than $90 \%$ of the organic content to be recovered.

\section{CRITERIA 4 \\ Societal benefits}

Up to 150 people will be involved in the construction of the facility in Northwich, which will permanently employ up to 24 people once fully operational.

\section{CRITERIA 5 \\ Business model innovation}

When operational, the Northwich site will generate around 5 megawatts of renewable electricity via the production of biogas. 



\title{
Outro
}

These nine cases represent how companies find new innovative ways to upgrade sidestreams and waste from bio-based resources in order to unlock their full potential. Companies in areas such as agriculture, household waste and meat and fish production have all succeeded in creating new, high-value products from previously unexploited raw materials, which has helped them to open up new markets and diversify their production. For example, several fisheries' companies have upgraded their technology to improve the utilisation rate and, increase the value of every fish caught, and develop innovative products and ingredients that cater to new markets while substantially reducing food and environmental waste and associated costs. Scaled up and replicated, these initiatives could represent substantial steps in reducing food waste from industry. In the agricultural sector, the materials previously regarded as waste by slaughterhouses and dairies can be turned into products that have superior nutritional qualities. Progress is also being made in the development of high-value products such as chemical components from plant material, while raw materials as diverse as seaweed, whey and meat residues serve as protein-rich feedstock.

In several of the cases, facilities and technologies may yet be further improved in order to maximise the benefits of utilising and upgrading sidestreams. Nonetheless, these cases show that upgrading has already had a positive impact not only on the companies' bottom line but on the environment and local communities. These cases exemplify the enormous environmental and business opportunities inherent in upgrading waste and sidestreams in areas such as agriculture and fisheries. More companies are expected to follow suit and improve their technology, processes and business models in order to create value-added products from sidestreams.

\author{
These cases exemplify the \\ enormous environmental \\ and business opportunities \\ inherent in upgrading waste and \\ sidestreams in areas such as \\ agriculture and fisheries.
}



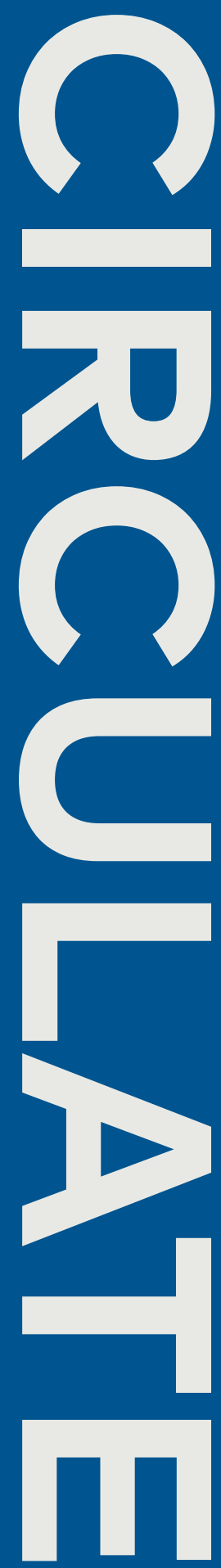


\title{
CIRCULATE \\ - creating self-sustainable, local and circular bio-solutions
}

The bioeconomy is not always circular - and the circular economy is not always bio-based. However, closing the loop is an important strength in the 'new' Nordic bioeconomy. A good example of this is the development of multi-trophic aquaculture, in which the various by-products, including waste, from one aquatic species are used as input (fertiliser/food) for another species or vegetative cultivation. Another example is the utilisation of waste as fertiliser in agricultural or forest production. However, while these cases are important, they are not strictly "circular". In the bioeconomy, a narrowly defined concept of circularity is not realistic - a fish is not returned to the sea after use, nor is a tree returned to the forest.

The circularity of the bioeconomy must be defined more broadly, in a way that takes into account the sustainability of the ecosystems and their ability to replace the annual harvest of biological material. The regeneration processes must not entail significant negative externalities, e.g. pollution, loss of biodiversity or adverse climate effects. The circular bioeconomy's ecosystem-based approach requires extensive scientific knowledge about the functions of the different ecosystems, as well as the implementation of surveillance systems to monitor their status and development.

The more we rely on bio-based resources - i.e. the more surpluses we harvest the more difficult it becomes to ensure sustainable utilisation in the long term. All of the Nordic countries have met or exceeded the limits of their ecosystems due to excessively intensive agriculture or fishing, or unsustainable forestry practices. However, in many cases, the damage has proven to be reversible. Strict compliance with the principles of sustainable harvesting, combined with low population density and a strong knowledge base, have resulted in an unusually large and healthy stock of natural resources in the Nordic countries. A circular approach to the utilisation of these stocks will, therefore, allow for resource renewal. These conditions form the principle of circularity in the Nordic bioeconomy. Another aspect of the circular bioeconomy concerns the way in which producers and authorities develop symbiotic and self-sustainable solutions in a local or regional context.

\author{
A circular approach to the \\ utilisation of these stocks will, \\ therefore, allow for resource \\ renewal.
}




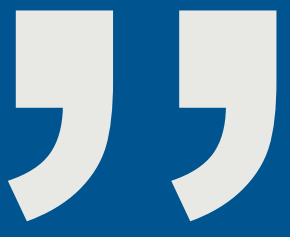

Seaweeds

are fast-

growing and

their farming

counteracts

loss of oxygen

in the ocean 


\title{
Seaweed for food, feed and fuel
}

\author{
Seafarm / Sweden
}

Seafarm is an interdisciplinary research project between four universities with the aim to grow, cultivate, and use macroalgae for the production of food, feed, bioenergy, and other bio-based materials in an integrated biorefinery focusing on creating a circular bio-production. The project partners use a holistic approach where utilisation of the resource is maximised in each step of the cycle. The seaweed will be cultivated at the Swedish west coast, where methods suitable for preservation and storage are investigated. The approach supports an overall goal to develop a sustainable system for the use of seaweeds as a renewable resource.

Seaweed farming avoids several of the disadvantages related to land-based biomass production for example the need for fertilisers and irrigation - and does not compete with the need for arable land. In addition, seaweeds are fast-growing and their farming counteracts loss of oxygen in the ocean. The Seafarm project is part of the Swedish Research Council Formas' targeted investment in the development of a bio-based economy, and the multi-disciplinary research team will collaborate closely with a set of state agencies, commercial enterprises, and other stakeholders in the different tasks of the project.

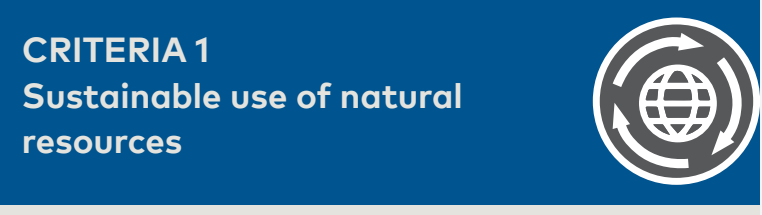

The utilisation of all resources are maximised in each step of the cycle and residues from the biorefinery are utilised for production of biogas and bio-fertilisers.

\section{CRITERIA 3}

Environmental benefits

Algae do not require input of energy, fertiliser, or water, which lessens the environmental impact compared to conventional farming and fuel production.

\section{CRITERIA 4}

Societal Benefits

Algae contain omega-3 fatty acids and proteins that are beneficial to human health, making it valuable as a food and feed ingredient. 


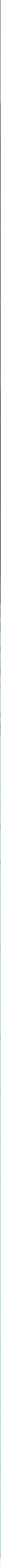




\section{The Blue Lagoon industrial symbiosis}

The Geothermal Resource Park / Iceland

The Resource Park is a cluster of different companies built around two geothermal power plants operated by HS Orka in Iceland's Reykjanes region. The companies in the Resource Park form an industrial symbiosis where waste streams from one company are used as valuable raw materials for other companies in the area. The operations and companies in the Resource Park cover various areas and industries including fish drying, seafood by-product processing, and warm-water aquaculture. Companies participating in The Resource Park are also involved in the areas of microalgae cultivation and ingredient production, methanol production from $\mathrm{CO}_{2}$, biotech greenhouse production, supplements from geothermal water, and green-energy data centers.

HS Orka's waste stream of geothermal water is benefitting a number of companies. The most wellknown being the Blue Lagoon - an artificial lagoon formed by the runoff from the power plant with more than 800,000 visitors per year. The area took a hit in 2006, when a U.S. Air Force base closed down. However, major efforts by the local public authorities have ensured that the former base is now partly converted into an innovation hub housing several startups and established companies with a connected university campus.

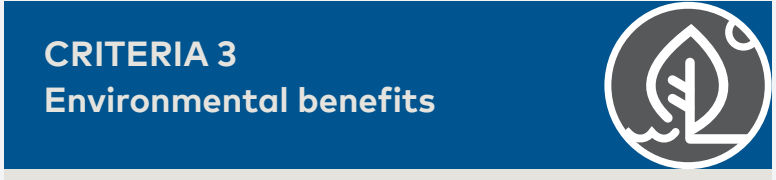

Compared to fossil fuels, the carbon footprint from using the geothermal energy is less than $5 \%$.

\section{CRITERIA 4}

Societal Benefits

One of every four new jobs created in Iceland's Southern Peninsula can be attributed to The Resource Park.

\section{CRITERIA 5}

Business model innovation

The low cost of the ample geothermal energy provides a major cost advantage for the local companies. 


\title{
Responsibly produced rainbow trout
}

\author{
Raisogro Ltd / Finland
}

The Benella project and brand involves replacing oil from marine fish with rapeseed oil as the main source of feed for rainbow trout. The Benella brand supports the marketing efforts of fish farmers involved in the project, as they can promote their sustainably fed rainbow trout, strengthening their competitiveness compared to companies that import fish. Branding the fish with Benella is free of charge for participating fish farmers if they live up to Benella's sustainable feeding concept by Raisioaqua, the brand owner. Benella was founded in collaboration between fishmeal producer Salmonfarm Ltd, 10 fish farming companies, a processor and retailer, Kalatukku E. Eriksson, as well as wholesalers Stockmann and Kesko.

The Benella concept is a good example of new selfsustainable and local solutions as it helps to conserve diminishing marine resources, as the traditional fish oil is largely replaced with regional rapeseed oil in feed during certain stages of growth. Additionally, fish oil usage is optimised in order to conserve the high levels of omega-3 fatty acids, EPA, and DHA, in the fish, which can lower blood pressure and heart rate as well as improve blood vessel function in humans. Benella uses locally sourced marine ingredients, which minimises nutrient load from outside the Baltic Sea.

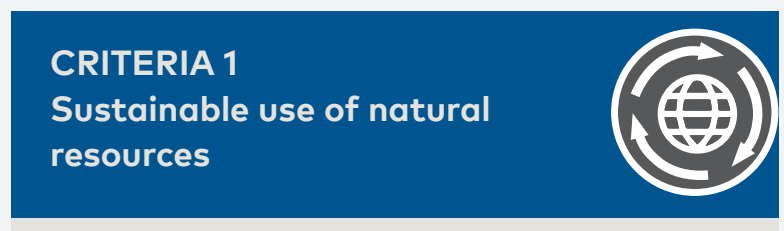

Adding the phytase enzyme to the feed improves the fish's digestion of vegetal phosphorus and increases the proportion that can be exploited by the fish, meaning $26 \%$ less phosphorus load from fish farming. Furthermore, locally sourced marine ingredients in the feed improve the nutrient balance in Baltic Sea.

\section{CRITERIA 2}

Technology innovation

The project partners plan to involve digital technologies enabling customers to track the end-product back to an individual fish farm.

\section{CRITERIA 5}

Business model innovation

Benella includes a new contract model for the aquaculture sector and involves marketing of companies that are distinct from the brand owner. 


\title{
Regional industrial symbiosis
}

\author{
Digipolis / Finland
}

The Kemi-Tornio region in northern Finland has established an Arctic industry and circular economy cluster to enhance industrial symbiosis and strengthen the development of a holistic bioeconomy in the region. Via extensive analysis of the by-products and residue streams from companies in the region, value-added products are now being produced by combining and rethinking several by-product and residue streams. Examples include silvicultural thinning practices, bioenergy from forest residues with the possibility for future for largescale biofuel production, as well as two plants that enable recovery of metals from slags from the steel and ferrochrome production in the region.

The Kemi-Tornio region is important for industrial refinement and exports, as it is responsible for $80 \%$ of Lapland's industrial production. At the same time, the area is compact, with a radius of $25 \mathrm{~km}$, and provides excellent industrial symbiosis conditions as it generates a total of 1.7 million tonnes of industrial by-products and residues annually from a large ecosystem of mines, metal producers, pulp and paper mills, a cardboard factory, and fertiliser and fine chemical producers. The bioeconomy initiative commenced at the request of the companies in the region, and is focused on using a cross-sectoral approach to create maximum value from the many by-products and residues. The Kemi-Tornio region plans to evolve from factory level optimisation through symbiotic products towards full-scale industrial symbiosis and circular economy.

\section{CIRCULATE}

\section{CRITERIA 5}

Business model innovation

The initiative focuses on creating new value chains and viable business cases based on the 1.7 million tonnes of by-products and

residues annually.

CRITERIA 1

Sustainable use of natural

resources

New steel products created in the region contain an average of almost $90 \%$ of recycled steel.

\section{CRITERIA 4}

Societal benefits

A total of 14 potential industrial symbiosis business cases have been identified in the region; these investments could employ more than 300 people. New large-scale bioeconomy investments and circular value chains could provide up to 500 new jobs in the ecosystem. 



\title{
Outro
}

The four cases in this chapter lie at the intersection between the bioeconomy and the circular economy. As such, they describe diverse approaches to a form of circular bioeconomy, based on, e.g. the optimisation of processes, integrated biorefineries and decreasing the phosphorus load from aquaculture, as well as using renewable rapeseed oil for fish feed. However, they also represent a more holistic approach, in which regions and universities have embraced the concepts of the bioeconomy and the circular economy in order to create more symbiotic and self-sustainable solutions with a reduced environmental impact. In one case, the overall goal is to develop a sustainable system for the use of seaweeds as a renewable feedstock for food, feed and other bio-materials. Another case consists of a cluster with impressive results and ambitious plans for circulating material and residues between a large ecosystem of companies that include mines, metal producers, and pulp and paper mills.

Taken together, these cases illustrate that the transition to a bioeconomy and circular economy, based on renewable raw materials, entails research and development, collaboration and marketing of the end products. Central to this will be exploring local production synergies and utilising and growing more local resources. An increasing number of countries is embracing the bioeconomy and circular economy at national policy level, as both a driver for growth and a way of using natural resources more sustainably and efficiently. Among the challenges that lie ahead are ongoing dissemination of information and exchanging of knowledge about best and next practices, and better communication of the clear financial and environmental benefits of circulating resources between a greater number of companies and organisations.

\author{
Taken together, these cases \\ illustrate that the transition \\ to a bioeconomy and circular \\ economy, based on renewable \\ raw materials, entails research \\ and development, collaboration \\ and marketing of the end \\ products.
}



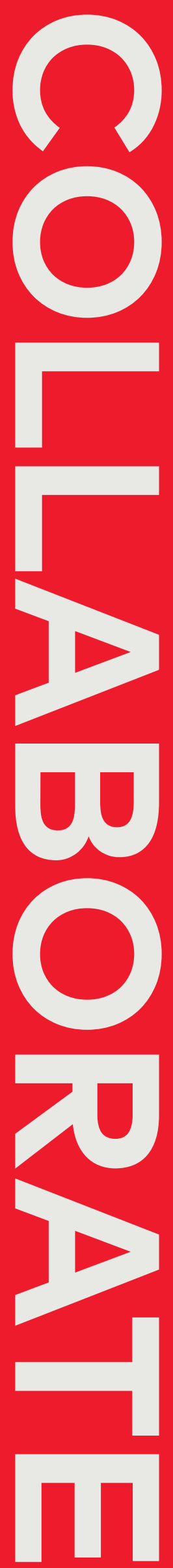


\section{COLLABORATE \\ - because we are smarter together}

The Nordic societies are characterised by a high level of social capital and trust. They also share a long history of both sectoral and local collaboration, not least in traditional bioeconomy industries such as agriculture, forestry and fisheries. This provides a good starting point for building the collaborative structures needed to develop the new bioeconomy further.

The 'new' Nordic bioeconomy depends upon collaboration. Unlike older approaches, the new bioeconomy aspires to be circular and place-based, rather than sector-specific. The emphasis is on utilising sidestreams, upgrading by-products and replacing fossil-based materials. Fully utilising all of the different fibres, enzymes and short- and long-chain molecules requires extensive collaboration between various partners on multiple levels. Companies in different sectors must align their processes in order to optimise resource utilisation; R\&D institutions must work closely with the private sector to provide innovative solutions, and regional authorities must collaborate with industry to ensure the right infrastructure is in place, and the appropriate incentives are offered. Collaboration is crucial for the successful development of the Nordic bioeconomy's other three pillars: replace, upgrade and circulate.

Collaboration and innovation across sectors are complicated and entail numerous challenges. The rewards and financial gains are uncertain, and may not be distributed in proportion to the partners' investments. The relevant companies may be competitors and rivals with no interest in creating synergies. And more often than not, traditional customer-competitor business models or organisational structures do not readily lend themselves to collaboration. Many of these obstacles can, however, be overcome by partnerships between the public and private sector. This theme, therefore, demonstrates how public and private stakeholders can facilitate efficient collaboration.

\section{Collaboration and innovation across sectors are complicated and entail numerous challenges.}




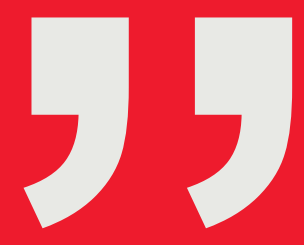

Reaching zero

waste and

becoming a

non-carbon

economy 


\section{Town transition to a carbon-neutral society}

The municipality of li / Finland

The municipality of $\mathrm{li}$, with less than 10,000 inhabitants, is committed to reaching zero waste and becoming a non-carbon economy, utilising only local and renewable resources for energy, transportation, and production. Public buildings in li are either equipped with ground-sourced heat, solar panels, or connected to the district heating network with bioenergy as its primary energy source. The city recently reached a level in which all of its electricity is generated by wind turbines, small- and large-scale hydropower, and solar energy; in fact, li produces nine times more green energy than the town uses itself. On the path to zero waste, li has launched a new system in which biowaste is collected and fed into a digestion plant for biogas production. Biogas will likely replace liquefied petroleum gas (LPG) in the industrial sector.

Ii is larger than traditional ecovillages, but the local aspect remains a cornerstone in the town's transition. To support local producers and inform consumers, li created its own certificate, which is given to producers for using local employees, services, and locally produced feedstock and energy. Similarly, a scheme ensures that surplus food from municipal kitchens and citizens is sold or donated to the poor to minimise or remove waste streams, while the remainder of the waste is recycled, made into biogas, or combusted and used for heating.

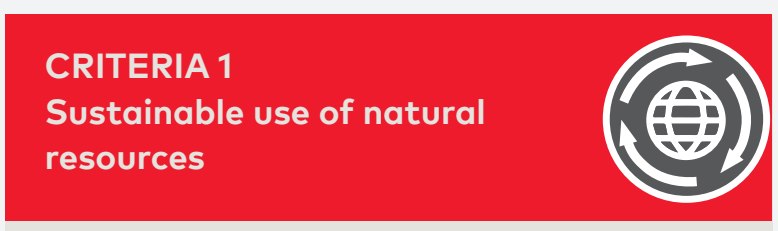

A waste collection scheme for biowaste is currently being implemented, turning biowaste in to biogas.

\section{CRITERIA 3}

Environmental benefits

The long-term investments in renewable ener$g y$, energy efficiency, and a zero-waste society have reduced $\mathrm{CO}_{2}$ emissions by 63,000 tonnes from 2007 to 2013 , making li a frontrunner in carbon reductions in Finland according to the Finnish Environmental Institute.

\section{CRITERIA 4}

Societal benefits

Within bioenergy, in the form of wood chips, and wind power alone, more than 50 new jobs have been created since 2012. The new green solutions are also used to engage locals for the development of their living environment, and the town has experienced a rise in community commitment and participation.

\section{COLLABORATE}




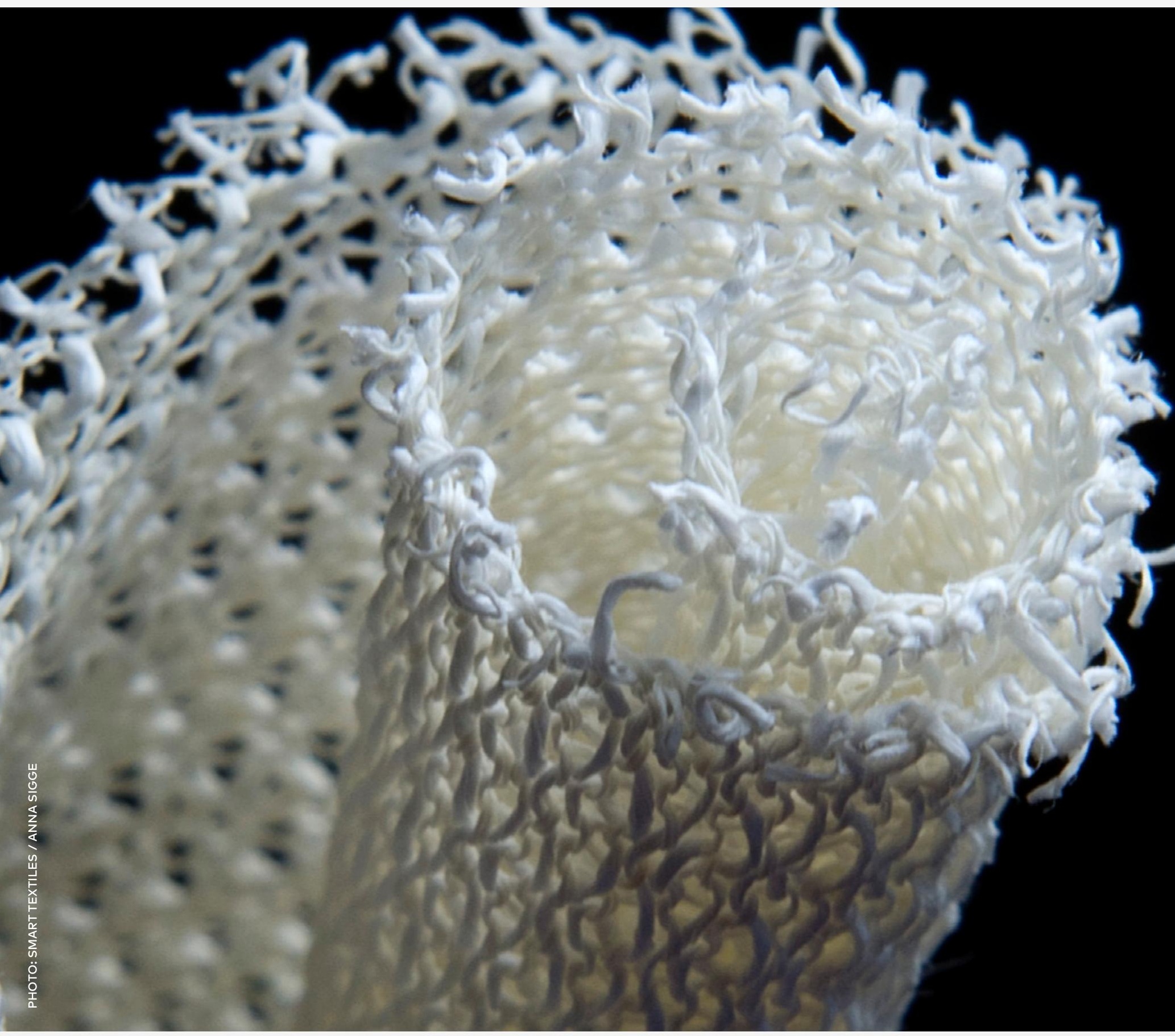




\title{
From technology park to biorefinery cluster
}

\author{
SP Processum / Sweden
}

SP Processum launched in 2003 as a technology park, but has since evolved into a cluster host for development, upscaling, and commercialisation of biorefinery processes. Processum, which is owned by RISE Research Institute of Sweden and 22 companies, cooperates with other biorefinery initiatives, industry partners, and academic institutions to develop new products, processes, and energy solutions from wood raw material and residual streams from other industry processes. Having access to a large biorefinery area and a large network within academia and business, SP Processum is able to connect individuals and companies with good ideas to the relevant partners, helping them to test their ideas, commercialise, and scale up their ideas.

The cluster plays an important role in the development of products in areas such as organic chemistry, biofuels, and other biotechnologies. Products and projects also include textiles produced from wood fibres, green chemicals, biofuels, animal feed, enzymes, and gelling agents. SP Processum also hosts the regional growth initiative and hub for forest biorefinery development with the approach that anything made out of oil can be also be made of wood.

\section{CRITERIA 1 \\ Sustainable use of natural \\ resources}

The initiative in an excellent example of how a group of diverse stakeholders can achieve a significantly more efficient use of the raw forestry material by working together. SP Processum supports the development of new products based on renewable wood raw material as well as on residual streams from existing or future processes.

\section{CRITERIA 2 \\ Technology innovation}

The biorefinery is a test bed for constantly applying existing and new technology for sustainable purposes.

\section{CRITERIA 3 \\ Environmental benefits}

The production of textiles from cellulose offers a sustainable alternative to the cotton production which has a huge ecological footprint due to intensive use of pesticides and water.

\section{COLLABORATE}




\section{Innovation program for Swedish bioeconomy in 2050}

\section{Biolnnovation / Sweden}

Biolnnovation is a strategic innovation program with the vision of turning Sweden into a full bioeconomy by 2050. By connecting and supporting stakeholders from different industries and sectors, Biolnnovation aims to increase the value creation and competitiveness of bio-based materials, products, and services. The work is concentrated on four prioritized areas: chemicals and energy, materials, construction and design, and new utilization. The main priority for all programs is to substitute fossil-based resources with new bio-based resources to lower $\mathrm{CO}_{2}$ emissions. With the ambition of serving markets worldwide, the involved projects produce everything from wood-based textiles and smart packaging and transportation for food to 3D-printed prosthetics and bio-based chemicals.

The initiative started in 2014 and will run at least until 2026. Sixty partners are involved so far, with the number increasing constantly as new partners are welcomed on a rolling basis. The yearly total budget is planned to be around EUR 11 million, which is provided by public and private partners including Vinnova, the Swedish Energy Agency, and the Swedish Research Council Formas.

\section{CRITERIA 1 \\ Sustainable use of natural \\ resources}

The Biolnnovation program has supported KTH Royal Institute of Technology and partners in developing a model car with a roof and battery made from renewable wood-based carbon fibre.

\section{CRITERIA 3}

Environmental benefits

Several of Biolnnovation's projects aim to substitute less eco-friendly materials such as cotton and polyester with wood-based fibres that have the potential to greatly reduce the textile industry's environmental impact.

\section{CRITERIA 4}

Societal benefits

One of Biolnnovation's projects, "Renewable bio-based products in the health area" develops antibacterial and easily washable surfaces with integrated sensors to improve conditions in the health-care sector. 


\title{
A cluster that connects the dots
}

\author{
Paper Province / Sweden
}

Paper Province is a non-profit cluster organisation working to advance the forest-based bioeconomy and showcase how a bio-based society could look like if we minimise our use of fossil-based products and fuels. Through collaboration between industry, academia, and public stakeholders, member companies improve their products, services, and competitiveness, contributing to overall growth in the region. The organisation represents the entire value chain and associated services as member companies range from multinational corporations to local suppliers. Paper Province is able to support participating companies and inventors with knowledge and capital on their way from concept through pilot testing to commercial deployment.

The region hosts more than 200 companies linked to the pulp and paper industry that stand to benefit by exploiting each other's waste streams. Examples include mills delivering their waste heat to surrounding neighbourhoods, a company producing soil improvement products from mill waste, and an open test bed enabling companies to develop and scale up technologies to refine lignin to climate-friendly fuels, chemicals, and materials.

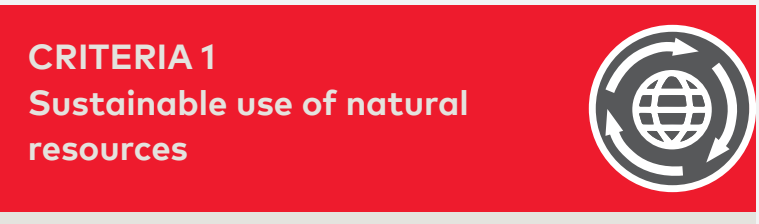

Paper Province has supported the company Cellcomb in inventing a closed food pad in cellulose, which offers $50 \%$ longer shelf life for poultry, meat, and fish.

\section{CRITERIA 3}

Environmental benefits

Paper Province's business incubator has supported the development of a dewatering screw press that reduces the energy consumption by $95 \%$ compared to traditional thermal drying processes.

\section{CRITERIA 4}

Societal benefits

A long-term goal for the initiative is to contribute to the transformation of the region to an innovative bio-based society that contributes to sustainable industrial growth and generates many new jobs in existing and new businesses.

\section{COLLABORATE}




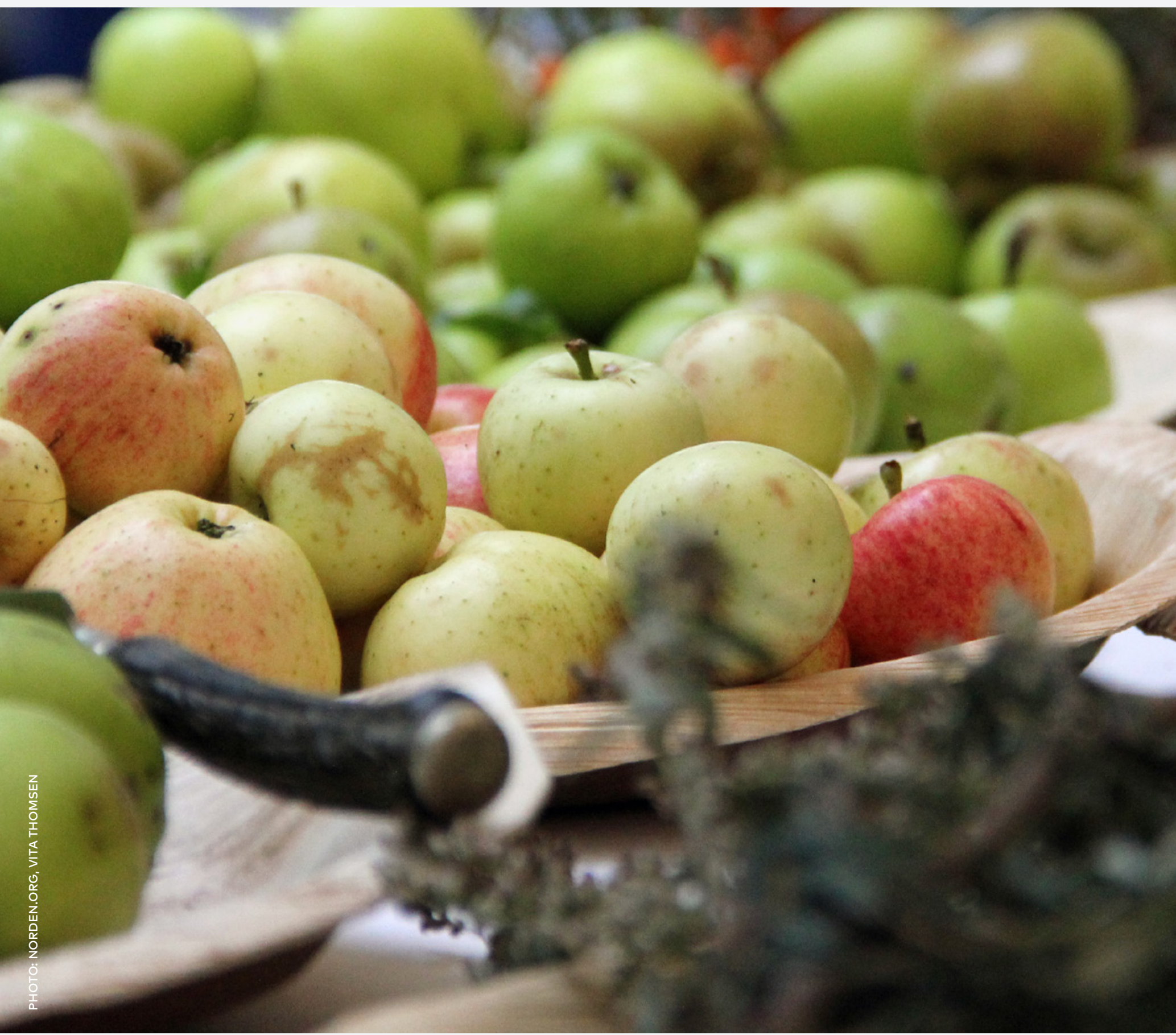




\title{
Reinventing the local value chain
}

\author{
Sodankylä Municipality / Finland
}

Based on a strong agricultural and forestry tradition, Sodankylä municipality is reinventing the food value chain to support locally produced and processed food and minimise food waste. Today's centralized delivery systems often exclude local produce and products, but by designing and modifying the system for smaller deliveries from local communities, the city hopes to overcome delivery and storage issues faced by kitchens. The aim of the project, which is inspired by pre-industrial organisation is to increase demand for local produce and create growth opportunities for small- and medium-size enterprises to stimulate the local economy and reduce food waste. During the project, food waste has already decreased by $20 \%$ and the import of food reduced by $30 \%$.

The municipality itself has introduced a central kitchen that produces 1,500 meals per day made from local ingredients. With a new design of the supply chain and procurement system, the kitchen uses local ingredients instead of imported industrial semi-finished or convenience food, thereby creating local value and decreasing capital outflow from the region. The locally cultivated and produced food ingredients include meat, fish, berries, and root vegetables.

\section{CRITERIA 1 \\ Sustainable use of natural \\ resources}

Sodankylä municipality has decreased food waste by $20 \%$ by reinventing the supply chain and logistics around food.

\section{CRITERIA 4}

Societal benefits

Studies suggest that locally produced, less processed food is better for human health compared to conventional foods. In Sodankylä, locally purchased ingredients contain no additives or perservatives, and none are added in the cooking process. This contributes to increased public health in the area.

\section{CRITERIA 5}

Business model innovation

Sodankylä is improving conditions for entrepreneurship in the municipality by creating demand for local produce and increasing profitability by cutting logistics costs.

\section{COLLABORATE}




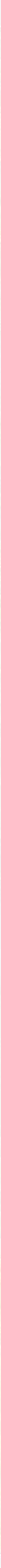




\title{
Local transition to a knowledge- based bioeconomy
}

\author{
Skagafjörour and Fisk Seafood / Iceland
}

Skagafjörður, the "Food Fjord" of Iceland, has traditionally been dominated by classic fisheries and agriculture. The transition to a knowledge-based bioeconomy means local companies are now hiring scientists to work on improved utilisation and upgrade of marine raw materials. The establishment of a science park has supported substantial collaboration, new innovative companies, and the creation of hundreds of interconnected jobs across different bio-based industries. In response to the $30 \%$ reduction on the total allowable catch of cod, in 2007, the fjord Skagafjörður embraced the bioeconomy to generate new revenue streams. With a wealth of raw materials and a diverse range of companies proximate to one another, Skagafjörður only needed to develop the infrastructure supporting the growth of a knowledge-based bioeconomy.

Fisk Seafood is a good example of Skagafjörður's transition to a flourishing bioeconomy. The company has developed methods to utilise previously unused cuts of fish to produce high-value products rich in proteins. Fisk Seafood has decreased their waste generation, and their new approach has allowed them to diversify their production. The diversified product portfolio consists of marine proteins and food supplements with bioactive functions as well as leather made from fish skin.

\section{CRITERIA 1 \\ Sustainable use of natural \\ resources}

Fisk Seafood is utilising cuts of fish previously considered waste.

\section{CRITERIA 4}

Societal benefits

The transformed labour market and knowledge jobs paved the way for young professionals to settle in the area. $30 \%$ of the workforce in Skagafjörður now holds a university degree.

\section{CRITERIA 5}

Business model innovation

With the production of bioactive food supplements, Fisk Seafood has diversified their product portfolio and entered a new market.

\section{COLLABORATE}





\section{Outro}

The six cases presented here show that collaboration is crucial for realising the full benefits of the bioeconomy. Collaboration is often characterised by public-private partnerships, in which various actors - regions, cities, research institutions, companies and other public and private entities - work together on ambitious policies, plans and clusters, and share a common goal of developing new innovative bioeconomy solutions. The different stakeholders also benefit from each other's resources, either by exchanging knowledge and involving universities in order to co-create and utilise the best research and ideas in the field, or by actually exchanging physical resources, where companies form symbiotic clusters in which they utilise each other's sidestreams as feedstock for new products. Some of the cases show that communities, too, have set a diverse range of ambitious goals - from zero-waste to reinventing the value chain for local food production - and have worked with business and civil society to achieve them.

While a few of the projects presented have already had considerable success, many still need to take additional steps with regard to implementation, development and commercialisation. Taken together, however, these cases are good examples of how stakeholders across sectors show great eagerness and a strong will to collaborate in order to accelerate the transition towards a bioeconomy, with positive benefits in terms of new products, revenue streams, job creation and better utilisation of resources. Collaboration is not only crucial at local, regional and national level, but across all levels, too. Companies and countries alike will benefit from working together across borders to share knowledge and information on the best ways of unlocking the bioeconomy's full potential as fast as possible.

\section{Collaboration is not only crucial at local, regional and national level, but across all levels, too.}




\section{Breaking out of the shell}

The 25 cases in the catalogue illustrate the four "strongholds" of what could be the 'new' Nordic bioeconomy. Together, they present solutions for global challenges, based on a vision of a smarter, more sustainable and more inclusive society.

The replace cases demonstrate the many ways in which bio-based resources can replace fossil-based or other unsustainable resources. For example, companies are turning wood into high-value products that can replace petroleum-based alternatives, reducing the environmental footprint. It is sometimes questioned whether these resources use arable land that could otherwise have been used for food production, but the cases presented here use residuals previously regarded as waste. The more traditional use of wood as construction materials is furthermore an important driver for sustainable buildings. Taken together, replacement is, therefore, an important pillar in the Nordic bioeconomy in which biomass is not only used to produce energy, heat and fuel but replace a wide range of unsustainable products.

This leads to the next pillar: upgrading. Here, the cases represent how companies find new and innovative ways to upgrade sidestreams and waste from bio-based resources in order to unlock their full potential. Companies in areas such as agriculture, household waste, and meat and fish production have all succeeded in creating new and valuable products from previously unexploited materials. In several cases, the facilities and technology require further improvement in order to fully realise the benefits of utilising and upgrading waste materials, but the cases show that the upgrading of raw materials is already having a positive impact - not only on the bottom line but also the environment.

The circularity of the 'new' bioeconomy must be defined broadly in terms of the sustainability of the ecosystems, production and consumption. As such, the circulate cases overlap with several aspects of the replacement and upgrade approaches. The cases illustrate how exploring place-based production synergies and utilising and growing more local resources are central to realising a circular bioeconomy. Some cases also represent a more holistic approach, in which regions and universities have embraced the concepts of the bioeconomy and circular economy in order to create more symbiotic and self-sustainable solutions. 
Finally, the collaborate cases are good examples of how stakeholders collaborate across sectors to accelerate the transition towards a sustainable Nordic bioeconomy, with positive benefits in terms of new products, revenue streams, job creation and better resource utilisation. The stakeholders benefit mutually either in terms of sharing knowledge or symbiotically exchanging physical resources. Other cases show that communities, too, have set ambitious goals - from zero-waste to reinventing the value chain for local food production - and have worked with a diverse range of partners to achieve them.

Taken together, the 25 cases illustrate that the development of the 'new' Nordic bioeconomy is driven by a wide range of stakeholders - institutions, small companies, big companies, clusters, civil society, local authorities, academia, governments and individuals. The focus is on bringing about a green transition through the replacement of unsustainable and fossil-based resources, through the upgrading of sidestreams and waste, and by creating circular and self-sustainable local solutions. We hope that the experiences and achievements presented here will inspire others to break out of the shell, innovate and devise their own solutions and forms of collaboration that will lead to a green transition.

Taken together, the 25 cases illustrate that the development of the 'new' Nordic bioeconomy is driven by a wide range of stakeholders - institutions, small companies, big companies, clusters, civil society, local authorities, academia, governments and individuals. 


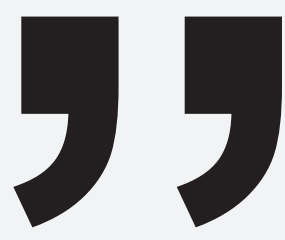

Nordic

bioeconomy

is about

sustainable

change 


\section{The Nordic Bioeconomy Panel}

\section{Country representatives:}

Hörður G. Kristinsson, chair (Iceland)

Liisa Saarenmaa (Finland)

Sölve Högman (Åland)

Casper Linnestad (Norway)

Stefan Källman (Sweden)

Lene Lange (Denmark)

Henrik Leth and Lisbeth Due Schönemann-Paul (Greenland)

Ólavur Gregersen (Faroe Island)

\section{Observers:}

Johan Elvnert (European Forest-based Sector Technology Platform)

Niels Gøtke (Danish Agency for Sciences, Technology and Innovation)

Kjell Ivarsson (Federation of Swedish Farmers)

Sirpa Kurppa Gøtke (LUKE Natural Resources Institute)

Per Hansson (Nordic Agri Research)

Jonas Rönnberg (Nordic Forest Research)

Helge Paulsen (Nordic working group on fisheries)

Lise Lykke Steffensen (Nordgen)

Jukka Teräs (Nordregio)

Hans Jørgen Koch (Nordic Energy Research)

Elisabeth Smith (Nordic Innovation)

Gunnel Gustafsson (NordForsk)

Project secretary and contact:

Liv la Cour Belling, Nordic Council of Ministers

For more information please visit

www.norden.org/en/theme/nordic-bioeconomy 


\title{
$\mathbb{1}$
}

\author{
Nordic Council of Ministers \\ Ved Stranden 18 \\ DK-1061 Copenhagen K \\ www.norden.org
}

\section{Nordic Bioeconomy - 25 cases for sustainable change}

The bioeconomy consists of the management of renewable biological resources and their conversion into food, livestock feed, bio-based products and bioenergy via innovative and efficient technologies. It involves tackling major challenges, both now and in the future. These include the sustainable production of sufficient nutritious and safe food for our growing population, developing new and more environmentally friendly sources of energy, and combating global warming, which can have serious consequences both on land and in the oceans.

In 2015, the Nordic Bioeconomy Panel was established with the mandate to develop a proposal on a joint Nordic bioeconomy strategy designed to stimulate innovation and support a sustainable transition in the Nordic bioeconomy. As a stepping-stone towards the strategy, the Nordic Council of Ministers and the Nordic Bioeconomy Panel have collaborated with the Danish think-tank Sustainia (Monday Morning) on collecting and categorizing 25 Nordic cases on the 'new' Nordic bioeconomy. This catalogue presents a selection of the many excellent cases that deserve attention but the selected cases seek to illustrate the diverse bioeconomy activities in the Nordic countries. We hope that they will inspire you and enhance your understanding of the bioeconomy, its importance and its potential. 